BNL- 64991

INFORMAL REPORT

\title{
COATINGS FOR PROTECTION OF EQUIPMENT FOR BIOCHEMICAL PROCESSING OF GEOTHERMAL RESIDUES: PROGRESS REPORT FY'97
}

Marita L. Allan

November 1997

\author{
RECEIVEO \\ JAN 269998 \\ OSTI
}

Prepared for:

Office of Geothermal Technologies

U.S. Department of Energy

1000 Independence Avenue, S.W.

Washington, DC 20585

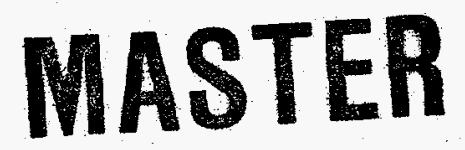

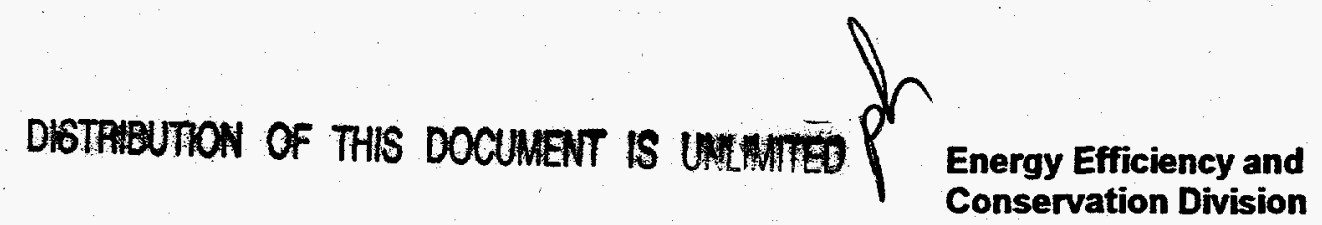

DEPARTMENT OF APPLIED SCIENCE

BROOKHAVEN NATIONAL LABORATORY

UPTON, LONG ISLAND, NEW YORK 11973 


\title{
COATINGS FOR PROTECTION OF EQUIPMENT FOR BIOCHEMICAL PROCESSING OF GEOTHERMAL RESIDUES: PROGRESS REPORT FY 97
}

\author{
M.L. Allan \\ Brookhaven National Laboratory
}

NOVEMBER 1997

Prepared for:

Office of Geothermal Technologies

U.S. Department of Energy 1000 Independence Ave., S.W.

Washington, D.C. 20585

Energy Efficiency and Conservation Division

Department of Applied Science

Brookhaven National Laboratory

Upton, New York 11973-5000

This work was performed under the auspices of the U.S. Department of Energy, Washington, D.C., under Contract No. DE-AC02-76CH000016. 


\section{DISCLAIMER}

This report was prepared as an account of work sponsored by an agency of the United States Government. Neither the United States Government nor any agency thereof, nor any of their employees, makes any warranty, express or implied, or assumes any legal liability or responsibility for the accuracy, completeness, or usefulness of any information, apparatus, product, or process disclosed, or represents that its use would not infringe privately owned rights. Reference herein to any specific commercial product, process, or service by trade name, trademark, manufacturer, or otherwise does not necessarily constitute or imply its endorsement, recommendation, or favoring by the United States Government or any agency thereof. The views and opinions of authors expressed herein do not necessarily state or reflect those of the United States Government or any agency thereof. 


\section{DISCLAIMER}

Portions of this document may be illegible electronic image products. Images are produced from the best available original document. 


\section{CONTENTS}

PAGE

SUMMARY. iv

1.0 Introduction... 1

1.1 Corrosion of 316L Stainless Steel.......................................... 1

1.2 Required Coating Properties.................................................. 2

1.3 Selected Coatings...................................................... 3

2.0 Experimental Procedure............................................................... 3

2.1 Specimen Preparation...................................................... 3

2.1.1 316L Stainless Steel............................................ 3

2.1.2 Thermal Sprayed Coatings............................... 3

2.1.3 Spray-and-Bake Fluoropolymers.......................... 4

2.1.4 Brushable Ceramic-Filled Epoxy........................... 4

2.2 Coupon Tests................................................................ 4

2.3 Atlas Cell Tests.............................................................. 5

2.4 Cathodic Disbondment Tests........................................ 6

2.5 Abrasion Tests.............................................................. 7

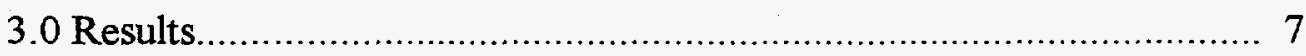

3.1 Coupon Tests............................................................. 7

3.2 Atlas Cell Tests............................................................. 7

3.3 Cathodic Disbondment Tests............................................ 20

3.4 Abrasion Tests.......................................................... 21

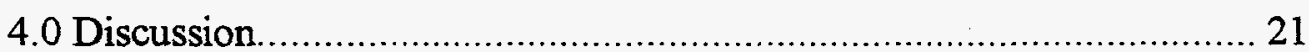

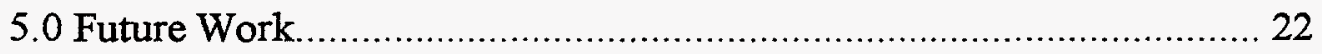

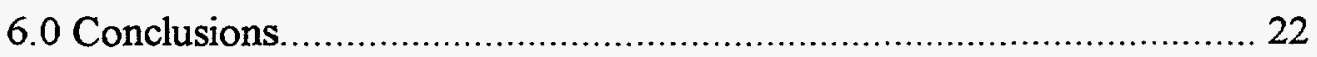

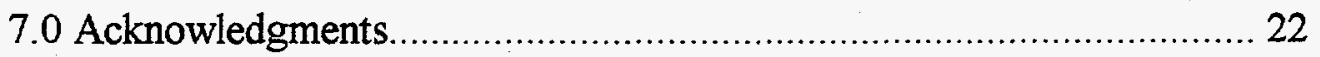

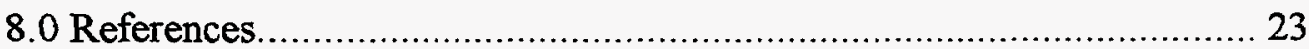




\section{SUMMARY}

Thermal sprayed ethylene methacrylic acid (EMAA) and ethylene tetrafluoroethylene (ETFE), spray-and-bake ETFE and polyvinylidene fluoride (PVDF) and brushable ceramicepoxy coatings were evaluated for corrosion protection in a biochemical process to treat geothermal residues. The findings are also relevant to other moderate temperature brine environments where corrosion is a problem.

Coupon, Atlas cell, peel strength, cathodic disbondment and abrasion tests were performed in aggressive environments including geothermal sludge, hypersaline brine and sulphur-oxidizing bacteria (Thiobacillus ferrooxidans) to determine suitability for protecting storage tanks and reaction vessels. It was found that all of the coatings were resistant to chemical attack and biodegradation at the test temperature of $55^{\circ} \mathrm{C}$. The EMAA coatings protected $316 \mathrm{~L}$ stainless steel from corrosion in coupon tests. However, corrosion of mild steel substrates thermal sprayed with EMAA and ETFE occurred in Atlas cell tests that simulated a lined reactor operating environment and this resulted in decreased adhesive strength. Peel tests to measure residual adhesion revealed that failure mode was dependent on exposure conditions. Long-term tests on the durability of ceramic-epoxy coatings in brine and bacteria are ongoing. Initial indications are that this coating has suitable characteristics. Abrasion tests showed that the ceramic-epoxy had good resistance to the abrasive effects of sludge. Thermal sprayed EMAA coatings also displayed abrasion resistance.

Cathodic disbondment tests in brine at room temperature indicated that EMAA coatings are resistant to disbondment at applied potentials of -780 to $-1070 \mathrm{mV} \mathrm{SCE}$ for the test conditions and duration. Slight disbondment of one specimen occurred at a potential of $-1500 \mathrm{mV}$ SCE. The EMAA may be suited to use in conjunction with cathodic protection although further long-term, higher temperature testing would be needed. 


\subsection{INTRODUCTION}

A biochemical treatment process to detoxify geothermal brines and sludges has been developed at Brookhaven National Laboratory (Premuzic, 1995). Geothermal fluids contain a variety of inorganic elements, heavy metals and radionuclides. These fluids and solids precipiated from the fluids at low temperature are considered hazardous and must be treated before disposal. The biochemical process uses microorganisms to convert toxic metals, including radionuclides, present in geothermal residues into soluble species. The residues can then be disposed in an economic and environmentally acceptable manner. The process also permits recovery of commercially valuable products such as silica for paint fillers, technical grade $\mathrm{KCl}$ and precious metals. The untreated residues are corrosive towards ferrous metals due to high chloride content and low $\mathrm{pH}$. Dissolved gases that may be present in brine such as $\mathrm{H}_{2} \mathrm{~S}, \mathrm{NH}_{3}$ and $\mathrm{CO}_{2}$ also contribute to corrosion. The biochemical treatment process typically operates at $\mathrm{pH}$ values of $1-2$ and temperatures of $50-55^{\circ} \mathrm{C}$. Furthermore, the biocatalyst itself is corrosive. Therefore, the corrosivity of both the biocatalyst and residue must be taken into account when selecting materials for processing equipment.

The biochemical process has been demonstrated on a laboratory scale and is now being scaled up. Stainless steel (316L) vessels were available for use in a pilot scale plant. However, coupons of this material underwent corrosion when exposed to the environments of interest and it was necessary to determine suitable protective coatings. In addition, coatings to protect a low cost construction material, such as mild steel, for the planned full scale plant were of interest.

A literature survey was conducted to select potential coating systems and predict the likely performance of $316 \mathrm{~L}$ stainless steel. Laboratory experiments were then conducted to evaluate coatings and compare the performance of coated steel against $316 \mathrm{~L}$. Resistance to attack by geothermal sludges and brines and sulphur-oxidizing bacteria (Thiobacillus ferrooxidans) was investigated.

\subsection{Corrosion of 316L Stainless Steel}

The corrosion behaviour of stainless steels depends on composition. $316 \mathrm{~L}$ is an austenitic stainless steel with a nominal composition of $2 \% \mathrm{Mn}, 16-18 \% \mathrm{Cr}, 10-14 \% \mathrm{Ni}$ and $0.03 \%$ (max.) C. It differs from Type 316 in that it has a lower carbon content in order to minimize carbide precipitation in the heat affected zone (HAZ) at welds. Corrosion resistance of stainless steels relies on protection imparted by a passive film. $316 \mathrm{~L}$ stainless steel is susceptible to corrosion, particularly pitting, and stress corrosion cracking in $\mathrm{HCl}$ and other high chloride (>1000 ppm) environments due to breakdown of the passive film (e.g., ASM, 1987; Scharfstein, 1977). Corrosion of 316,316L and other stainless steel in high temperature geothermal fluids has been investigated by others (e.g., Macdonald et al., 1979; Carter and McCawley, 1978; Cramer and Carter, 1980; Needham et al., 1979; Syrett et al., 
1980; Braithwaite and Lichti, 1980). Based on this previous research, Type 316L can be expected to undergo corrosion in geothermal residues with high chloride content.

Microbiologically influenced corrosion (MIC) is reviewed by Borenstein (1994) and Little et al. (1992). Sulphur-oxidizing bacteria pose a threat to ferrous metals because they oxidize sulphur or sulphur-bearing compounds to form sulphuric acid. One species of interest for treatment of geothermal residues, $T$. ferrooxidans, is capable of oxidizing ferrous iron in solution to ferric iron, in addition to oxidizing sulphur. T. thiooxidans is another sulphuroxidizing, acid-producing bacteria that has been linked to MIC. Weldments in austenitic stainless steels are also susceptible to MIC (Borenstein, 1993). Most of the literature on MIC of stainless steels refers to sulphate-reducing and iron-oxidizing bacteria. No specific information on corrosion of $316 \mathrm{~L}$ by $T$. ferrooxidans was found.

\subsection{Required Coating Properties}

Coatings for protection of the processing equipment from corrosion and abrasion needed to be resistant to chemical attack and biodegradation in the environments and temperature and $\mathrm{pH}$ range of interest. The coatings should be easy to apply as a continuous film to vessels, economic, low VOC, not require priming or post curing, and retain adhesion and protective behaviour throughout the design life of the equipment. Permeation of aggressive species through the coating should be prevented or minimized and the coating should withstand any corrosion products that may develop at the substrate. The use of elevated temperatures in the biochemical process and the interest for coatings in other geothermal environments requires consideration of thermal mismatch. Hence, the coatings should be able to withstand stresses induced at the interface due to different coefficients of thermal expansion between the coating and the substrate. Polymer or polymer-ceramic composite coatings were selected for investigation due to their wide use in the chemical processing industry and properties compatible with service requirements.

Polymers potentially meeting these requirements included epoxies, polyesters and vinyl esters (all with inorganic fillers), an ethylene methacrylic acid copolymer and fluoropolymers. Application methods for fluoropolymers include spray-and-bake and sheet linings. Examples of the latter for transport of corrosive chemicals are provided by Heffner (1992). The spray-and-bake method requires appropriately sized ovens and large pieces of equipment can only be applied at limited facilities. However, this application method may be of interest in geothermal environments for suitably sized workpieces. Sheet linings have a backing which can be used with an elastomeric adhesive.

The application methods selected for investigation were spraying, spray-and-bake and painting. Spraying included thermal spraying in which the polymer powder is melted and impacted against the preheated substrate where it solidifies. This is a $100 \%$ solids method that can be used in the field. Case histories of thermal sprayed ethylene methacrylic acid (EMAA) are provided by Loustannau and Horton (1994) and these include rail cars and 
wastewater clarifiers. EMAA can also be applied by conventional fluidized bed and electrostatic methods. The other form of spraying considered was conventional application of a liquid coating.

\subsection{Selected Coatings}

The coatings selected for initial evaluation were: thermal sprayed ethylene tetrafluoroethylene (ETFE) and ethylene methacrylic acid (EMAA) polymers, spray-and-bake ETFE and polyvinylidene fluoride (PVDF) and a brushable ceramic-epoxy. Other coatings may have potential for the application of interest. However, the long-term nature of the evaluations restricted the number of coatings that have been tested to date.

\subsection{EXPERIMENTAL PROCEDURE}

\section{1 Specimen Preparation}

\subsubsection{Stainless Steel}

Bare $316 \mathrm{~L}$ coupons $(25.4 \times 50.8 \times 3.2 \mathrm{~mm}$ ) were abraded with 120 silicon carbide paper to provide a uniform surface. In order to determine the corrosion resistance of welds, autogeneously welded $316 \mathrm{~L}$ coupons were also tested. The coupons were supplied by Metal Samples (AL) and had a 120 grit finish. The dimensions of the welded coupons were 19.0 $\times 50.8 \times 3.2 \mathrm{~mm}$.

\subsubsection{Thermal Sprayed Coatings}

The EMAA copolymer powder was supplied by PFS Thermoplastic Powder Coatings (PF 111). A PFS 124 Powder Pistol with fluidized powder feed was used to apply the EMAA coatings. The propane and compressed air pressures were 41 and $826 \mathrm{kPa}$, respectively. The standoff distance used for coating test panels was $30-40 \mathrm{~cm}$ and the traverse rate was $10 \mathrm{~cm} / \mathrm{sec}$. The flow rates of the fluidized bed, combustion air, powder carrier air and propane were $20-25 \mathrm{l} / \mathrm{min}, 20 \mathrm{~V} / \mathrm{min}, 50 \mathrm{l} / \mathrm{min}$ and $8 \mathrm{l} / \mathrm{min}$, respectively. After blasting with alumina grit the panels were preheated to $82^{\circ} \mathrm{C}$ and then sprayed.

The ETFE powder was supplied by DuPont. The powder was sprayed using a Eutectic + Castolin Terodyn 3000 gun with TecFlow 5102 Powder Feeder. An air shroud at $241 \mathrm{kPa}$ was used. Oxygen, acetylene and nitrogen pressures were 207,103 and $344 \mathrm{kPa}$, respectively. The standoff distance was $15 \mathrm{~cm}$ and the traverse rate was $10 \mathrm{~cm} / \mathrm{sec}$. The grit blasted substrates were preheated to $162^{\circ} \mathrm{C}$ before spraying. All thermal spraying in this project was conducted at the Thermal Spray Laboratory, Department of Materials Science and Engineering, State University of New York at Stony Brook. 


\subsubsection{Spray-and-Bake Fluoropolymers}

Mild steel coupons coated with PVDF and ETFE were supplied by General Plastics (NJ) for testing. The substrates were sandblasted, preheated and sprayed with fluoropolymer. The coupons were then baked in an oven to fuse the coating. The thickness of the PVDF coating was $1047 \pm 26 \mu \mathrm{m}$. The ETFE coatings had a thickness of $900 \pm 32 \mu \mathrm{m}$.

\subsubsection{Brushable Ceramic-Filled Epoxy}

The brushable ceramic-filled epoxy coating was supplied by ITW Devcon. Parts A and $\mathrm{B}$ were mixed at the recommended proportion and the coating was brush applied to alumina grit blasted mild steel panels. The thickness of the coatings was $1072 \pm 180 \mu \mathrm{m}$. The application method resulted in a relatively high variation in coating thickness.

\subsection{Coupon Tests}

$316 \mathrm{~L}$ stainless steel coupons coated with EMAA and mild steel coupons with baked PVDF and ETFE were exposed to untreated geothermal sludge, brine residue from the Geysers with $\mathrm{pH}=2.6$, synthetic hypersaline brine, and Thiobacillus ferrooxidans in an experimental set up conforming to ASTM G 31. The EMAA coating thickness was approximately $700 \mu \mathrm{m}$. Bare plain and welded coupons were also tested for comparison. Coupons were suspended in a heated glass flask to give exposure conditions corresponding to complete immersion, partial immersion and vapour zone. Three coupons per exposure condition were tested for all of the environments. The bare $316 \mathrm{~L}$ coupons were cleaned in a $\mathrm{HNO}_{3}$ solution at $60^{\circ} \mathrm{C}$ in accordance with ASTM G1-C7.1.

The untreated geothermal sludge had a water content of $40 \%$ by mass. In the dry state the sludge largely consisted of silica $(62 \%), \mathrm{Fe}_{3} \mathrm{O}_{4}+\mathrm{FeSiO}_{4}(15 \%), \mathrm{BaSO}_{4}+\mathrm{BaCl}_{2}$ $(4 \%)$ and $\mathrm{CaSO}_{4}+\mathrm{CaCO}_{3}(3 \%)$. The minor components included $6000 \mathrm{ppm} \mathrm{NaCl}, 1300 \mathrm{ppm}$ $\mathrm{KCl}, 6000 \mathrm{ppm} \mathrm{SrSO}_{4}, 3500 \mathrm{ppm} \mathrm{MnSO}_{4}, 300 \mathrm{ppm} \mathrm{AsS}{ }_{2}+\mathrm{FeAs}_{2}, 250 \mathrm{ppm} \mathrm{CuS}$ and 130 $\mathrm{ppm} \mathrm{ZnS}$. The $\mathrm{pH}$ of the wet sludge was 6.12 and the test temperature was $55^{\circ} \mathrm{C}$. The sludge was mechanically stirred and aerated throughout the test.

The synthetic brine consisted of $58,000 \mathrm{ppm} \mathrm{NaCl}, 25,000 \mathrm{ppm} \mathrm{CaCl}_{2}, 15,000 \mathrm{ppm}$ $\mathrm{KCl}, 1000 \mathrm{ppm} \mathrm{FeCl}, 930 \mathrm{ppm} \mathrm{MnCl}_{2}, 430 \mathrm{ppm} \mathrm{SrCl}, 410 \mathrm{ppm} \mathrm{LiCl}, 370 \mathrm{ppm} \mathrm{ZnCl}, 330$ ppm $\mathrm{H}_{3} \mathrm{BO}_{3}$ and $130 \mathrm{ppm} \mathrm{BaCl}$. The $\mathrm{pH}$ of the brine was 4.15 . The brine was aerated throughout the test.

The nutrient for the $T$. ferrooxidans bacteria was prepared from two parts. Part A

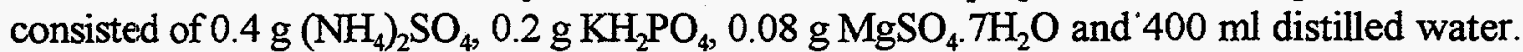
Part B consisted of $22.11 \mathrm{~g} \mathrm{FeSO} \mathrm{S}_{4} .7 \mathrm{H}_{2} \mathrm{O}, 1.0 \mathrm{ml} 1 \mathrm{~N} \mathrm{H}_{2} \mathrm{SO}_{4}$ and $100 \mathrm{ml}$ distilled water. Parts $\mathrm{A}$ and $\mathrm{B}$ were autoclaved separately and then combined aseptically. This was then inoculated with $T$. ferrooxidans. The $\mathrm{pH}$ of the $T$. ferrooxidans medium at the start of the test was 2.28 
and decreased to 1.98 throughout the course of the test. The temperature of the $T$. ferrooxidans medium was maintained at $55^{\circ} \mathrm{C}$ and the medium was changed every four weeks. Air was bubbled into the medium. For all environments the test duration was 12 weeks.

\subsection{Atlas Cell Tests}

The chemical resistance and corrosion protective nature of the coatings under simulated service conditions were determined following the test method described in ASTM C 868 (Atlas Cell Test). In this experimental arrangement coated panels were exposed to immersion and vapour zones, in addition to a temperature gradient from the external bare surface to the internal coated surface. This gradient simulated that which an internally heated reactor vessel would generate and is of importance since a temperature differential can accelerate permeation of the coating.

The test cell basically consisted of a horizontally-oriented, open-ended glass cylinder with a diameter of $152 \mathrm{~mm}$ to which the coated panels were clamped on the ends. Neoprene gaskets were placed between the glass and panel to provide a seal. The glass cylinder had ports for a thermometer, immersion heater, air bubbler and reflux condenser. The cylinder was partially filled with 1.21 of the solution of interest.

The test solutions were synthetic hypersaline geothermal brine (same composition as above) and $T$. ferrooxidans medium. The starting and final $\mathrm{pH}$ values of the $T$. ferrooxidans were approximately the same as those for the coupon tests and the medium was changed every four weeks. Air was bubbled into the test cells to provide agitation.

Mild steel panels, $191 \times 191 \times 6.3 \mathrm{~mm}$ (or $204 \times 204 \times 6.3 \mathrm{~mm}$ ), were grit blasted and coated with either EMAA, ETFE or Devcon Brushable Ceramic. The thickness of the EMAA coating exposed to brine was $1782 \pm 143 \mu \mathrm{m}$. The ETFE coating thickness was $463 \pm 61$ $\mu \mathrm{m}$. The thickness of the EMAA coatings for the $T$. ferrooxidans test was $768 \pm 106 \mu \mathrm{m}$. The test temperature was $55^{\circ} \mathrm{C}$ and the duration was 18 weeks in all cases. The temperature of the external bare steel surface was $43 \cdot 3-43.9^{\circ} \mathrm{C}$.

At the completion of the tests the coated panels were visually examined for signs of deterioration such as blistering, discolouration and loss of gloss. The residual adhesion was determined for EMAA coatings by measuring the peel strength (ASTM D 3167). The plates were cut into strips $25 \mathrm{~mm}$ wide and the orientation was vertical so that the strip traversed the vapour and immersion-exposed zones. The strips cut from the outer edges of the plates were beyond the exposure zone. A schematic diagram of the strips cut from the panels is presented in Figure 1 . The coatings were peeled back approximately $40 \mathrm{~mm}$ using a razor blade to enable the coating to be gripped. An Instron tensile testing machine was used. The crosshead speed was $152 \mathrm{~mm} / \mathrm{min}$. It was not possible to measure the peel strength of the ETFE coatings because the material was too brittle to bend $90^{\circ}$. 


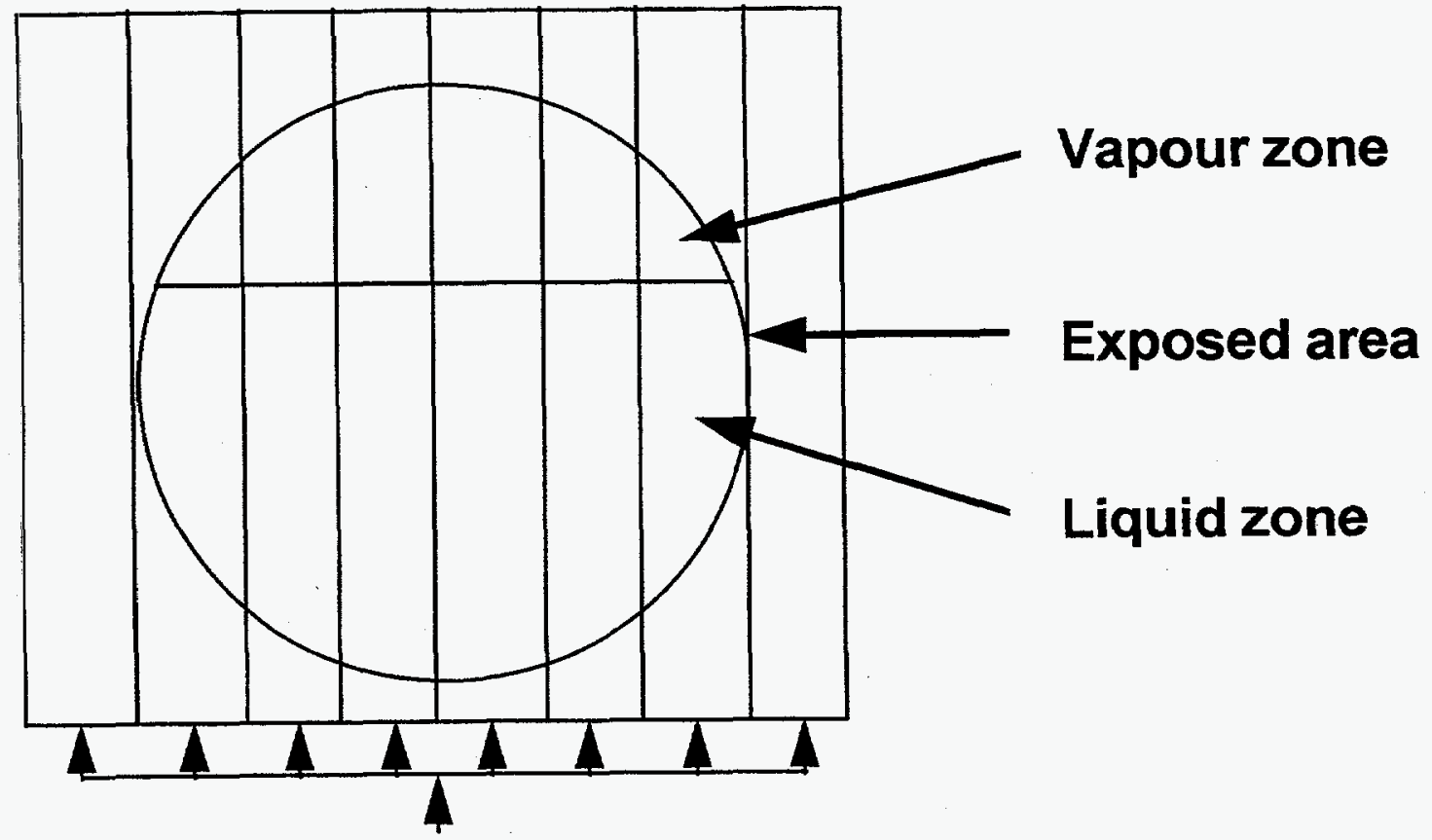

Strips cut from panel for peel tests

Figure 1. Schematic diagram of peel test specimens cut from Atlas cell panels.

\subsection{Cathodic Disbondment Tests}

The resistance of EMAA coatings to cathodic disbondment when exposed to an impressed current and hypersaline brine was determined. The objective was to determine whether disbondment around a coating defect would occur under cathodic protection. ASTM G 95 (Attached Cell Method) was used, although the specimen dimensions differed. Mild steel panels $104 \times 104 \times 4.7 \mathrm{~mm}$ were grit blasted and sprayed with EMAA. The average coating thickness was $1090 \pm 110 \mu \mathrm{m}$. A holiday (defect) of $3.2 \mathrm{~mm}$ diameter was created by drilling through the coating in the centre of the panel. A glass tube $76 \mathrm{~mm}$ diameter was attached to the coated panel with a silicone sealant. The tube was filled with brine and a Pt wire was used as an anode.

Four test potentials were used to reflect different levels of cathodic protection. These were $-780,-900,-1070$ and $-1500 \mathrm{mV} \mathrm{SCE}$. Potentials were monitored daily and adjusted as necessary. Tests were conducted on triplicate coated panels. In addition, control tests in which no cathodic protection current was applied were performed. The duration of the cathodic disbondment tests was four weeks and all tests were conducted at room temperature. At the completion of the tests the diameter of the holiday was measured and the surrounding coating inspected for disbondment. Future tests may examine the effect of temperature on disbondment. 


\subsection{Abrasion Tests}

A small scale test was performed to simulate the abrasion conditions to which a lined vessel containing continuously stirred geothermal sludge would be subjected. A 7.61 stainless steel tank with a diameter of $203 \mathrm{~mm}$ was grit blasted and coated on the internal surface with EMAA. The coating thickness was approximately $700 \mu \mathrm{m}$. The tank was half filled with sludge and stirred using a Jiffy mixer blade. Tests were conducted at room temperature and proceeded for two weeks. The coating was visually inspected for wear and the weight loss determined.

\subsection{RESULTS}

\subsection{Coupon Tests}

The uncoated $316 \mathrm{~L}$ coupons tested in untreated geothermal sludge underwent slight general corrosion when partially immersed or exposed to the vapour zone. The EMAA coated coupons did not exhibit any signs of deterioration. The bare $316 \mathrm{~L}$ coupons totally immersed in synthetic brine showed pitting corrosion with pit depths up to $1200 \mu \mathrm{m}$. Crevice corrosion also occurred underneath the PTFE spacer washers between coupons. The partially immersed coupons exhibited pitting corrosion just above the liquid level. Pits up to $1000 \mu \mathrm{m}$ deep were evident. No visible corrosion was observed for the bare coupons in the vapour zone of the synthetic brine.

Bare $316 \mathrm{~L}$ coupons exposed to the brine residue from The Geysers exhibited pitting and crevice corrosion when immersed or partially immersed. Evaporation caused salts to form at the liquid/vapour interface and corrosion was severe under these deposits, with pits up to $2000 \mu \mathrm{m}$. The coupons in the vapour zone displayed slight surface corrosion. Welded coupons did not undergo preferential corrosion in the brines. $316 \mathrm{~L}$ coupons coated with EMAA were unattacked by the brines. The baked PVDF and ETFE coatings also withstood the brine environments.

The tests in $T$. ferrooxidans showed that bare $316 \mathrm{~L}$ was susceptible to general corrosion in the vapour zone. The immersed bare coupons exhibited biofouling, although no corrosion was evident underneath the biofilm. No preferential corrosion in the HAZ of the welded coupons was observed. The EMAA coatings exposed to $T$. ferrooxidans did not show any visible signs of deterioration. Biofouling also occurred to a lesser degree on the immersed coated coupons. The biofilm was less adherent to the EMAA than the bare $316 \mathrm{~L}$. The baked ETFE and PVDF coatings were unaffected by the bacteria, although biofouling did occur.

\subsection{Atlas Cell Tests}

Figures 2 and 3 show the surfaces of the coated panels after testing. Staining due to 
evaporation of iron salts is evident at the transition between the liquid and vapour zones. One of the ETFE coated panels tested in brine exhibited eight blisters $5-10 \mathrm{~mm}$ in diameter below the liquid level and three blisters of the same diameter at the liquid/vapour interface. The blisters contained fluid and the coating was poorly bonded in the surrounding area. The coating could be peeled by hand as far as the gasket line. Where the coating was not exposed (outside the gasket), adhesion was sound. Corrosion had occurred where the coating was blistered. Spotty black corrosion products (probably $\mathrm{Fe}_{3} \mathrm{O}_{4}$ ) existed under the coating in the vapour zone. The spots were typically $2-5 \mathrm{~mm}$ in diameter. The coating was not blistered in these areas, but adhesion was decreased. The companion ETFE exposed to the same solution had one blister $5 \mathrm{~mm}$ in diameter below the liquid level and corrosion in the vapour zone. The black corrosion products tended to convert to red after exposure to air. The ETFE itself did not undergo any degradation.

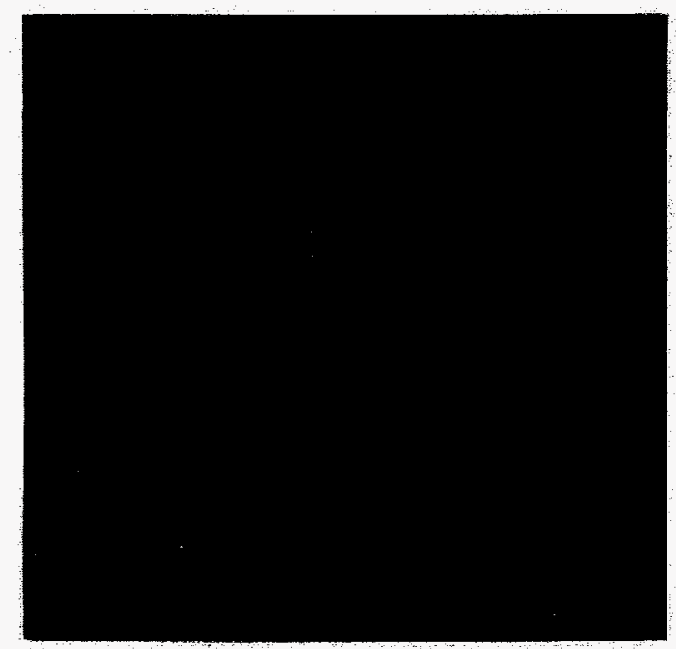

Figure 2. Surface of EMAA panel exposed to brine.

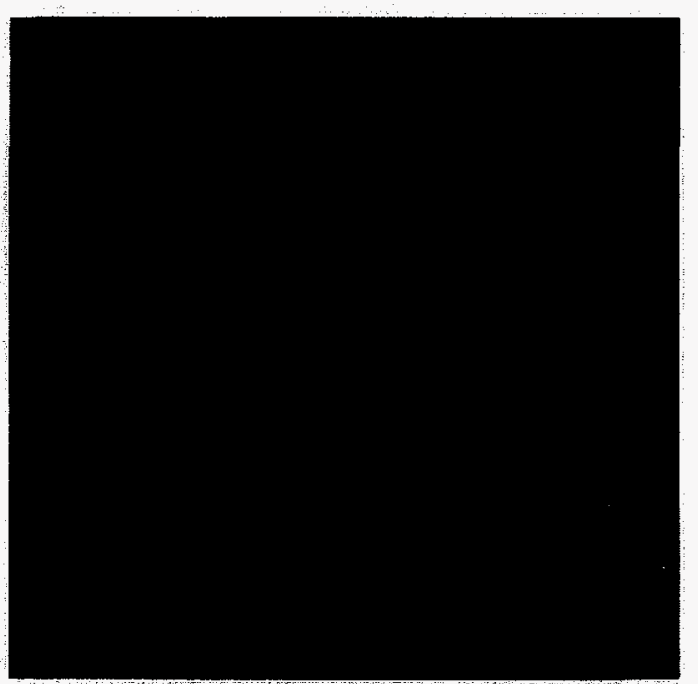

Figure 3. Surface of ETFE panel exposed to brine.

The EMAA coated panels exposed to brine did not exhibit any visible signs of deterioration. As shown in Figure 2, slight surface staining occurred, particularly in a 5-10 $\mathrm{mm}$ band at the liquid/vapour zone interface and this was attributed to evaporation of iron salts from the brine. Peel tests revealed black corrosion products beneath the coatings. In one panel, corrosion was more prevalent in the vapour zone, whereas the other exhibited corrosion in both the vapour and liquid zones. For the latter panel, the spots of corrosion in the upper half of the liquid zone were larger in diameter $(4-9 \mathrm{~mm})$ than those in the lower half and the vapour zone $(0.5-4 \mathrm{~mm})$. The spots of corrosion were randomly distributed. The failure load and mode were dependent on the presence of corrosion products. Failure was predominantly adhesive, although localized areas of cohesive failure within the polymer also occurred, particularly where the surface was free from corrosion. Mixed adhesive/cohesive failure was observed in a 5-10 mm band above the liquid level where the extent of corrosion was less than for other areas in the vapour zone. This band above the liquid level 
corresponded with the film of iron salts deposited on the coating external surface. It is proposed that the film acts as a sealant for the coating. Cohesive failure was also evident where the gasket contacted the coating. Corrosion products adhered to both the steel and polymer fracture surfaces.

Figure 4 depicts the peel load versus displacement curve for a strip cut from the edge of one of the panels. The coating in this location was not exposed to brine. The peel force was relatively constant and the failure mode was adhesive. The average peel strength was $4.33 \mathrm{~N} / \mathrm{mm}$. The steel and polymer surfaces after peeling are shown in Figure 5 . Figure 6 shows the results for a strip cut through an exposed area. The peel force was low in the initial region and this corresponded to the presence of corrosion products at the interface. The increase in peel force at higher displacement occurred outside the exposed area (at the gasket and beyond). Peel strength varied from 1.97 to $6.97 \mathrm{~N} / \mathrm{mm}$. Figure 7 shows the peeled steel and polymer surfaces. Figure 8 is another example of low peel forces in the corroded exposed area and increased values before and after this. Plastic deformation of the coatings occurred during peeling and this was concentrated in the areas outside the test cell where greater force was required to remove the coating. Figure 9 shows the peeled steel and polymer surfaces corresponding to the force-displacement curve in Figure 8 . All of the above tests were taken from the EMAA panel with corrosion in both the liquid and vapour zones.

The following peel test descriptions are for the panel exposed to brine with corrosion predominantly in the vapour zone. Figures 10 and 11 present typical peel test results for specimens cut through the exposed zone. Both of these figures show great variation in peel force along the length of the specimen. Low peel forces corresponded with the presence of oxides at the interface and adhesive failure. Increased forces in the exposed area correlated with cohesive or mixed adhesive/cohesive failure. Force required to peel the coating typically increased towards the end of the specimens beyond the test cell. In these specimens the peel strength varied from 0.98 to $10.87 \mathrm{~N} / \mathrm{mm}$. The surfaces of two of the specimens after peeling are shown in Figures 12 and 13. Cohesive failure of the polymer is evident, as are oxides predominantly in the vapour zone. The peel test result for a strip cut through the edge of the exposed zone is shown in Figure 14. Cohesive failure occurred beneath where the gasket contacted the polymer coating and peel strength ranged from 5.51 to $11.02 \mathrm{~N} / \mathrm{mm}$. Figure 15 shows the more constant force required to peel the coating outside the exposed zone. The average peel strength is around $5.51 \mathrm{~N} / \mathrm{mm}$.

Fracture surfaces from the EMAA-mild steel peel tests were examined under a scanning electron microscope (SEM). An example of mixed adhesive/cohesive failure in an uncorroded area is shown in Figure 16. The dark areas are polymer adhering to the steel surface. Spherical pores, $100-200 \mu \mathrm{m}$ diameter, in the polymer are evident and failure often occurred through these pores. Figure 17 is a higher magnification view of a fractured pore. Figure 18 shows the steel surface at the liquid/vapour transition zone. Spots of corrosion product are indicated. The polymer adhered to the steel in the uncorroded areas. Where corrosion occurred, failure was between the polymer and corrosion products, or within the 


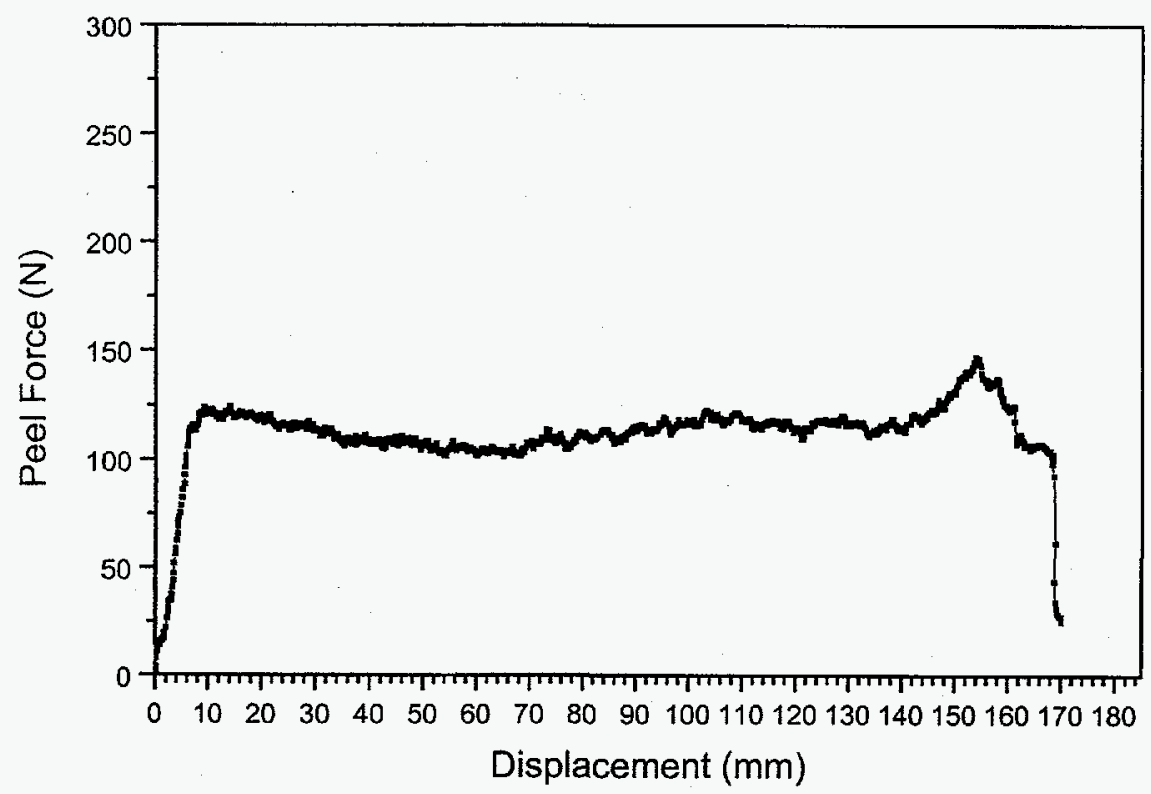

Figure 4. Peel force-displacement curve for EMAA outside brine-exposed zone.

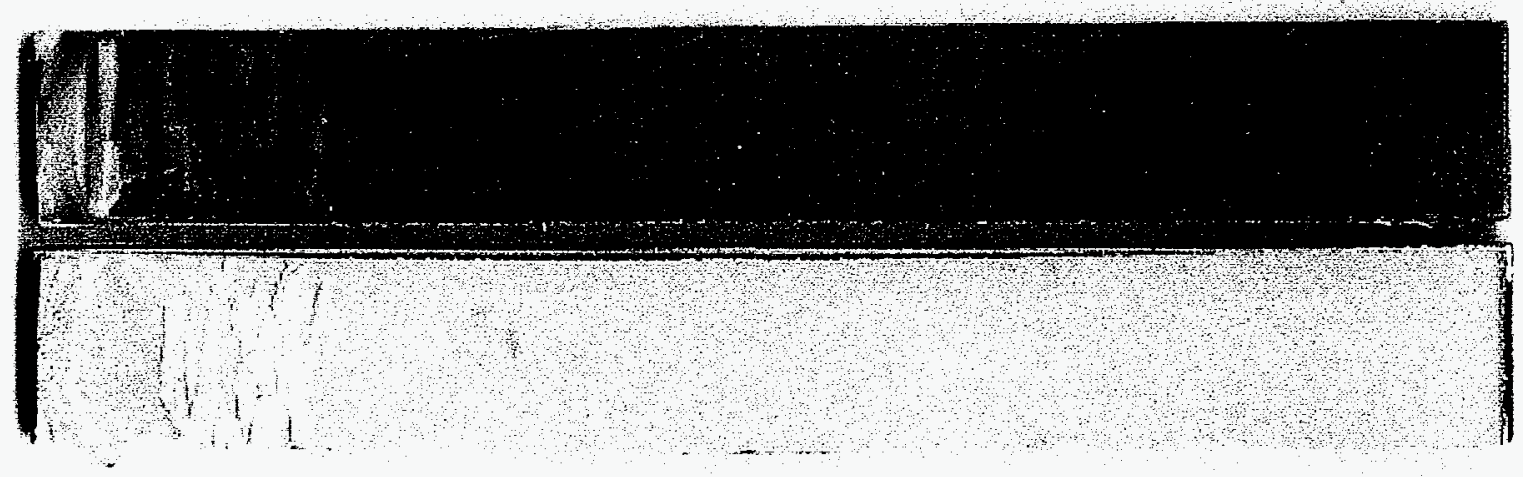

Figure 5. Steel and polymer fracture surfaces corresponding to Figure 4. 


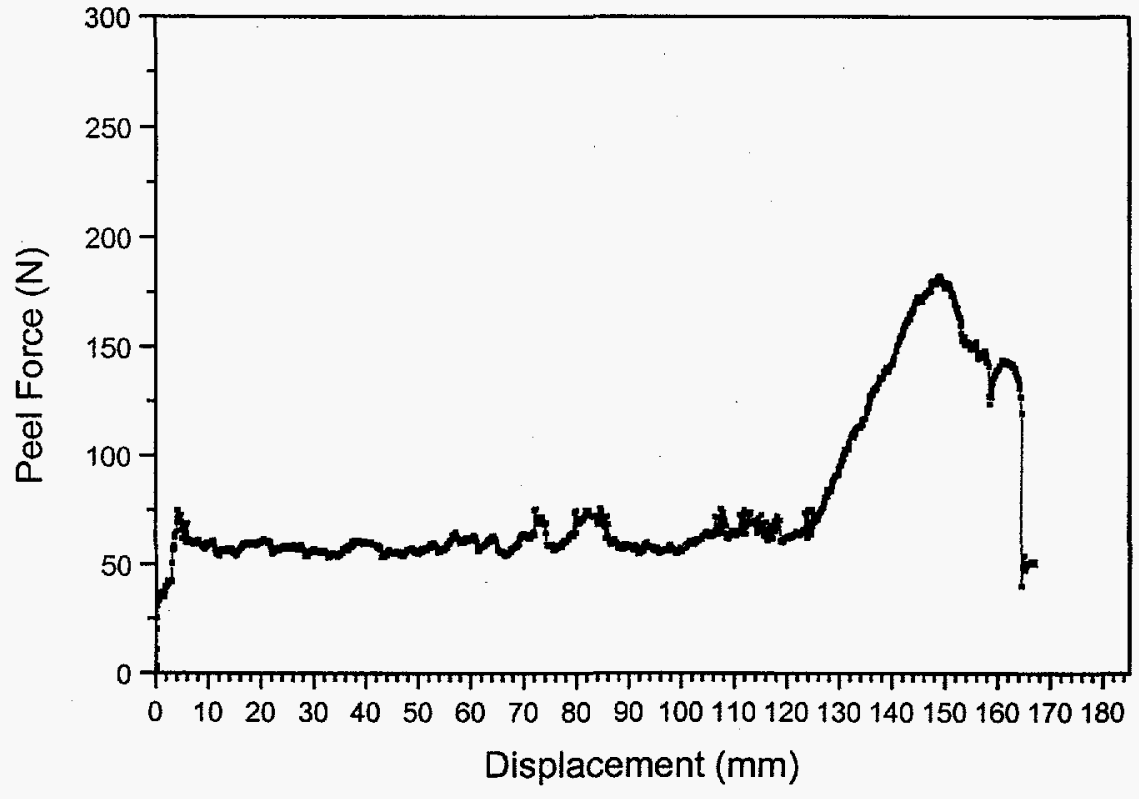

Figure 6. Peel force-displacement curve for EMAA exposed to brine.

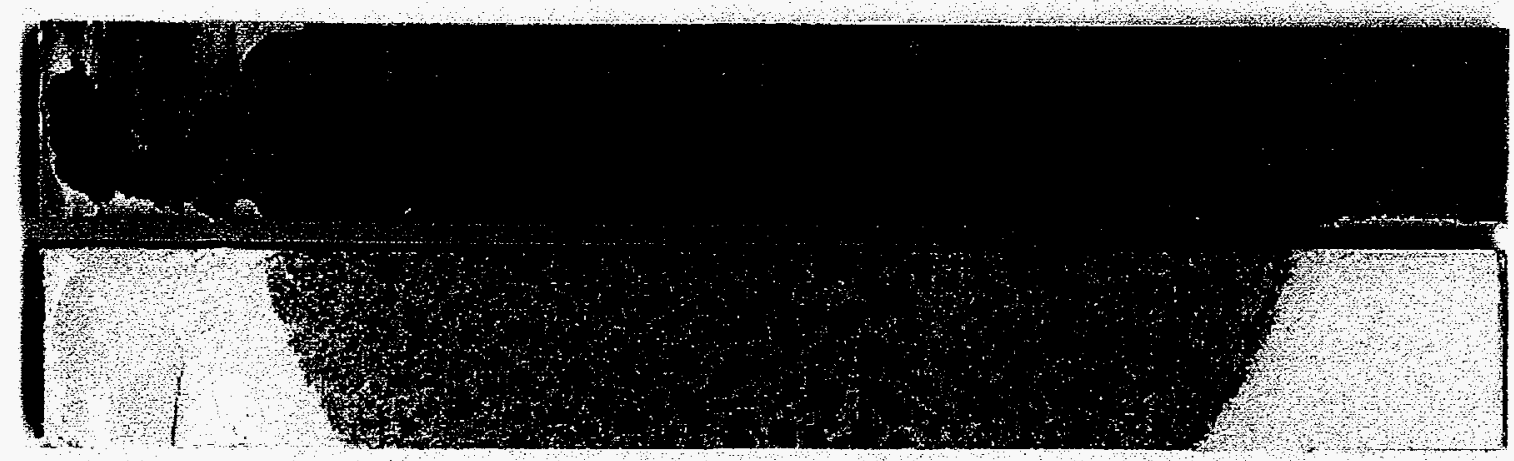

Figure 7. Steel and polymer fracture surfaces corresponding to Figure 6. 


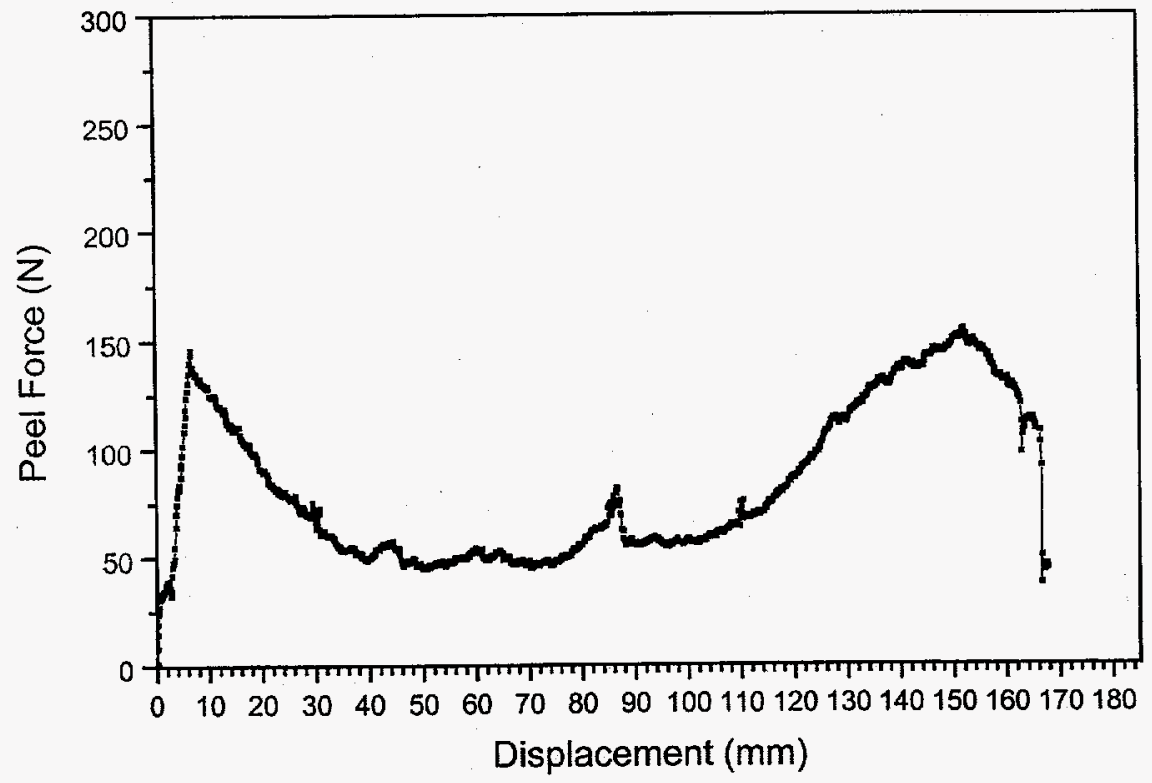

Figure 8. Peel force-displacement curve for EMAA exposed to brine.

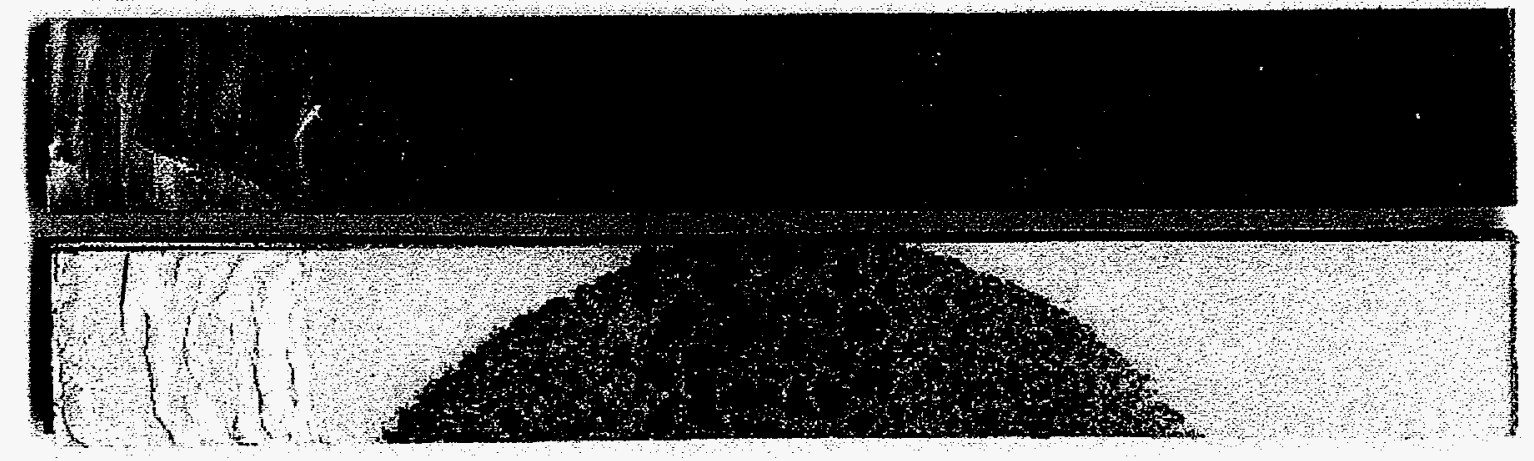

Figure 9. Steel and polymer fracture surfaces corresponding to Figure 8. 


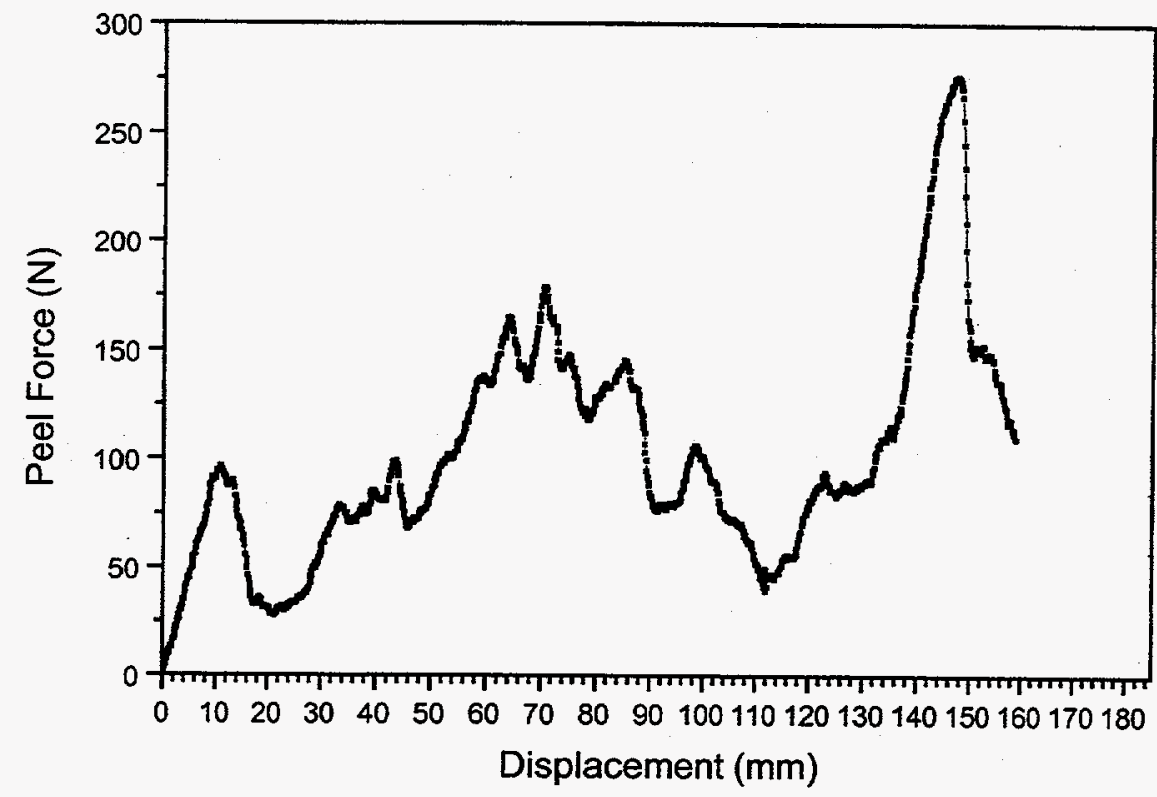

Figure 10. Peel force-displacement curve for EMAA exposed to brine.

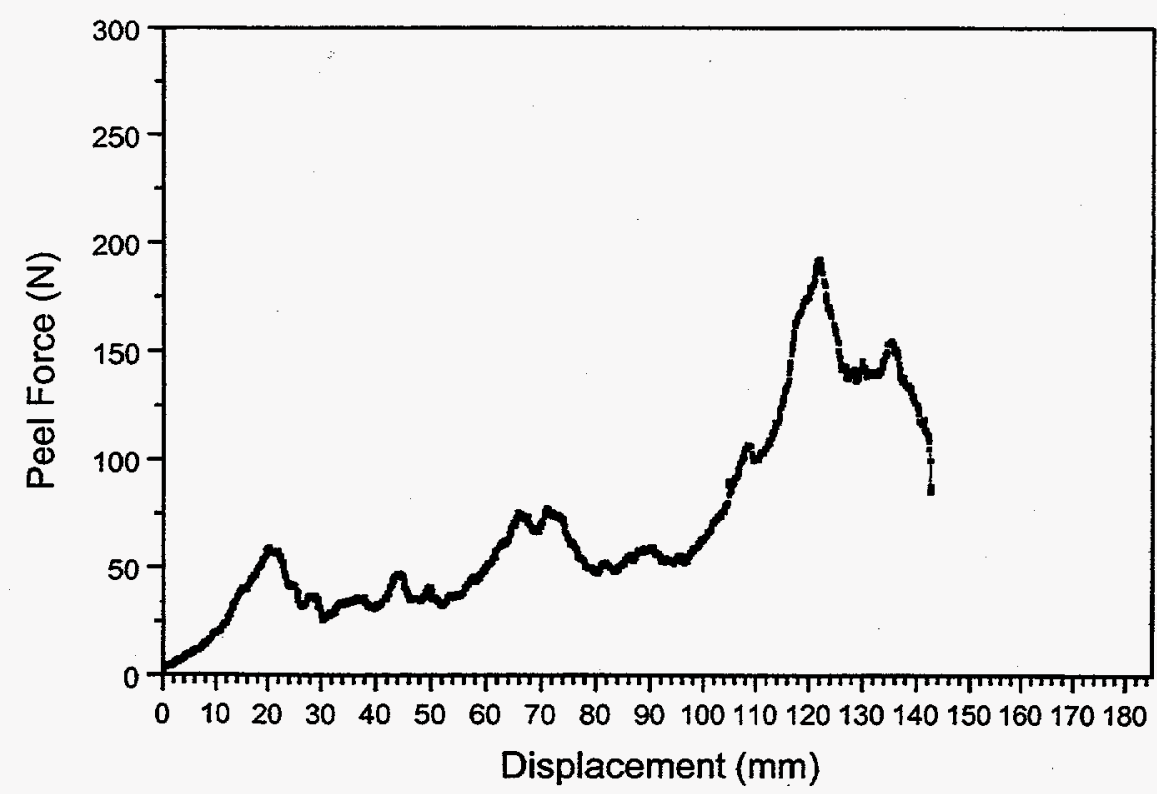

Figure 11. Peel force-displacement curve for EMAA exposed to brine. 


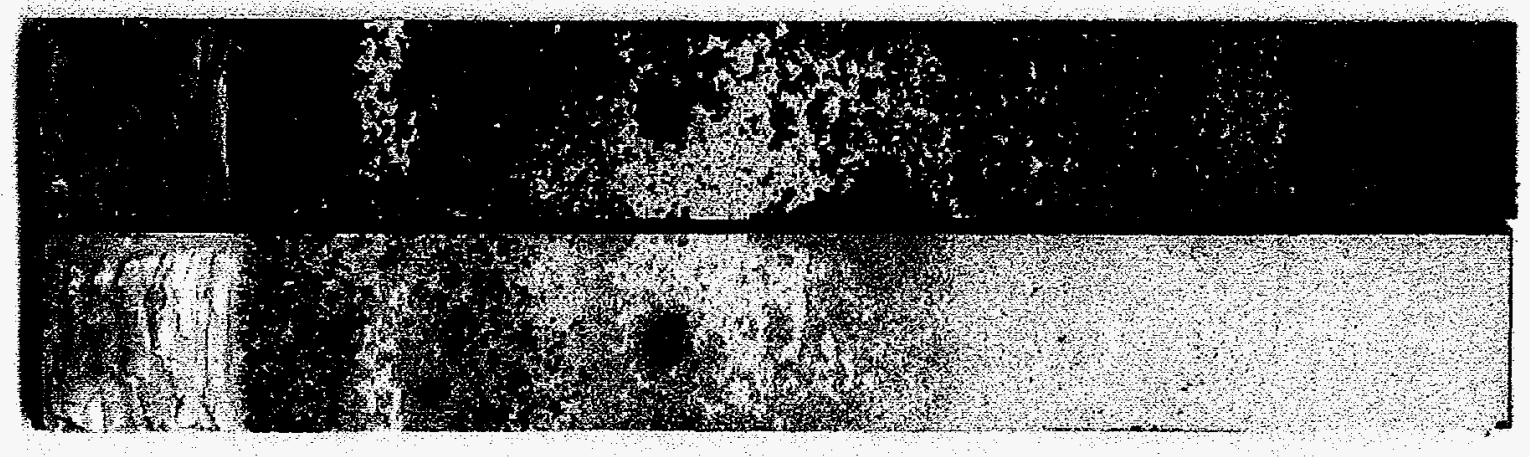

Figure 12. Steel and polymer fracture surfaces for EMAA exposed to brine.

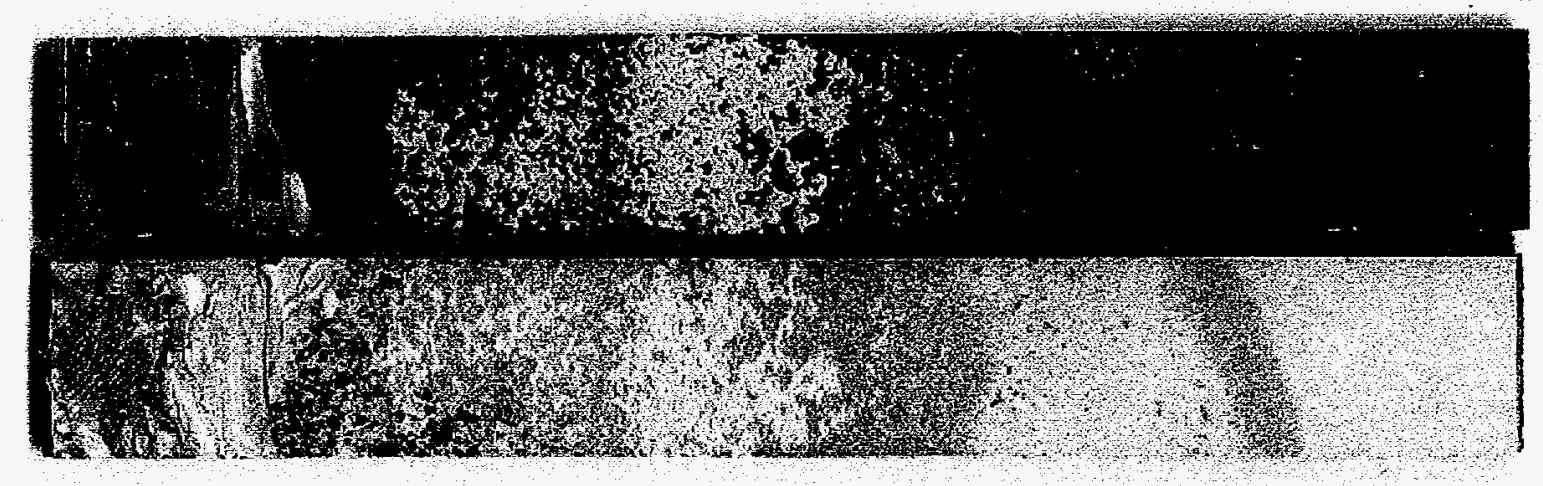

Figure 13. Steel and polymer fracture surfaces for EMAA exposed to brine. 


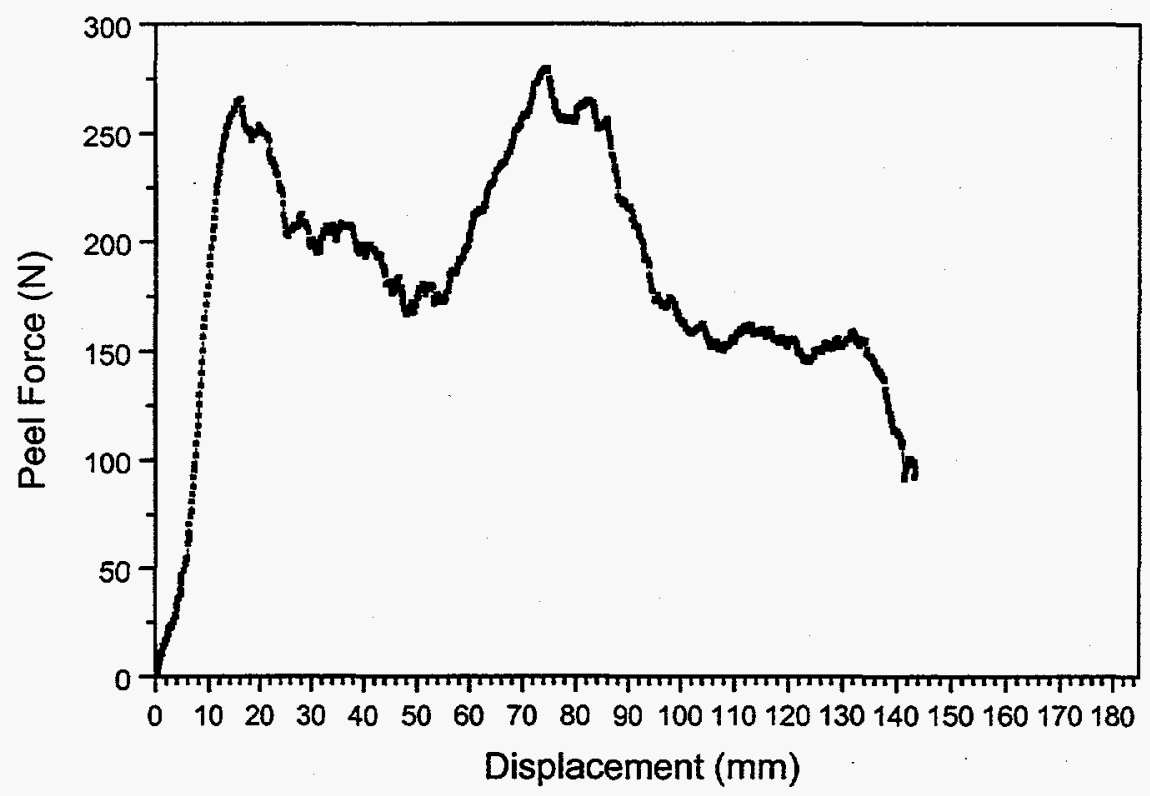

Figure 14. Peel force-displacement curve for EMAA at edge of brine-exposed zone.

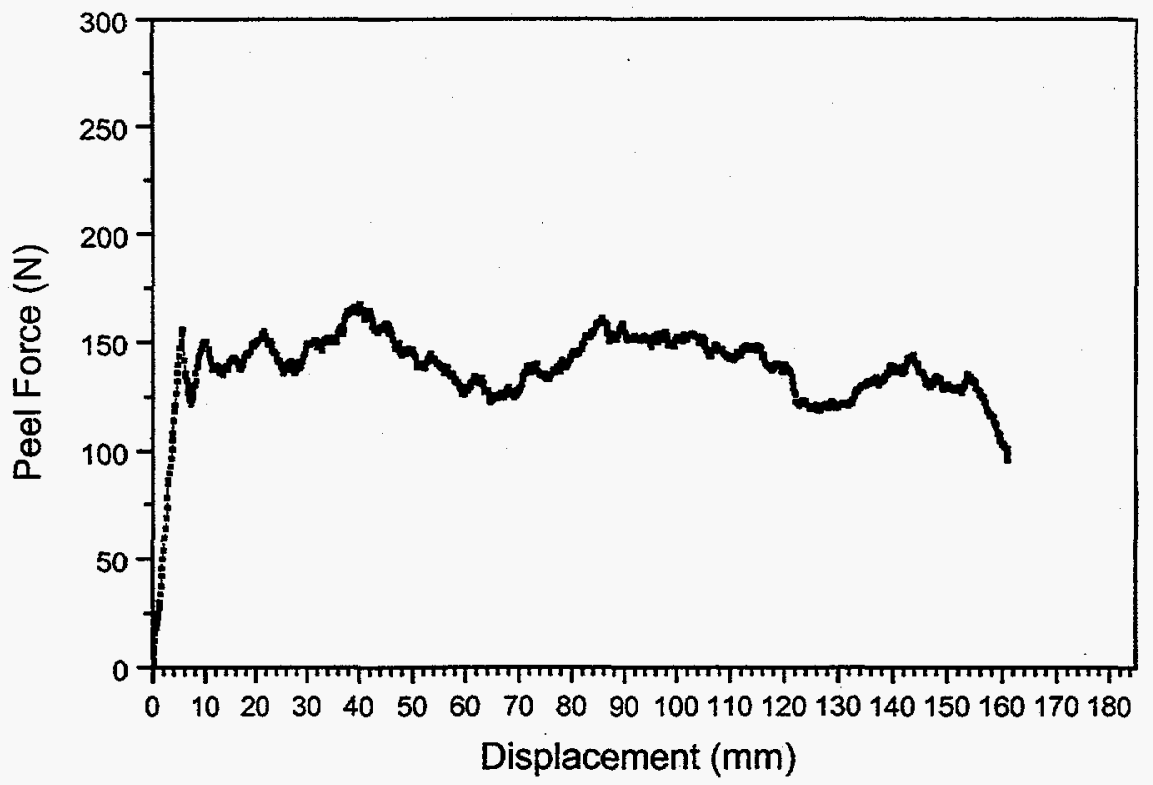

Figure 15. Peel force-displacement curve for EMAA outside brine-exposed zone. 


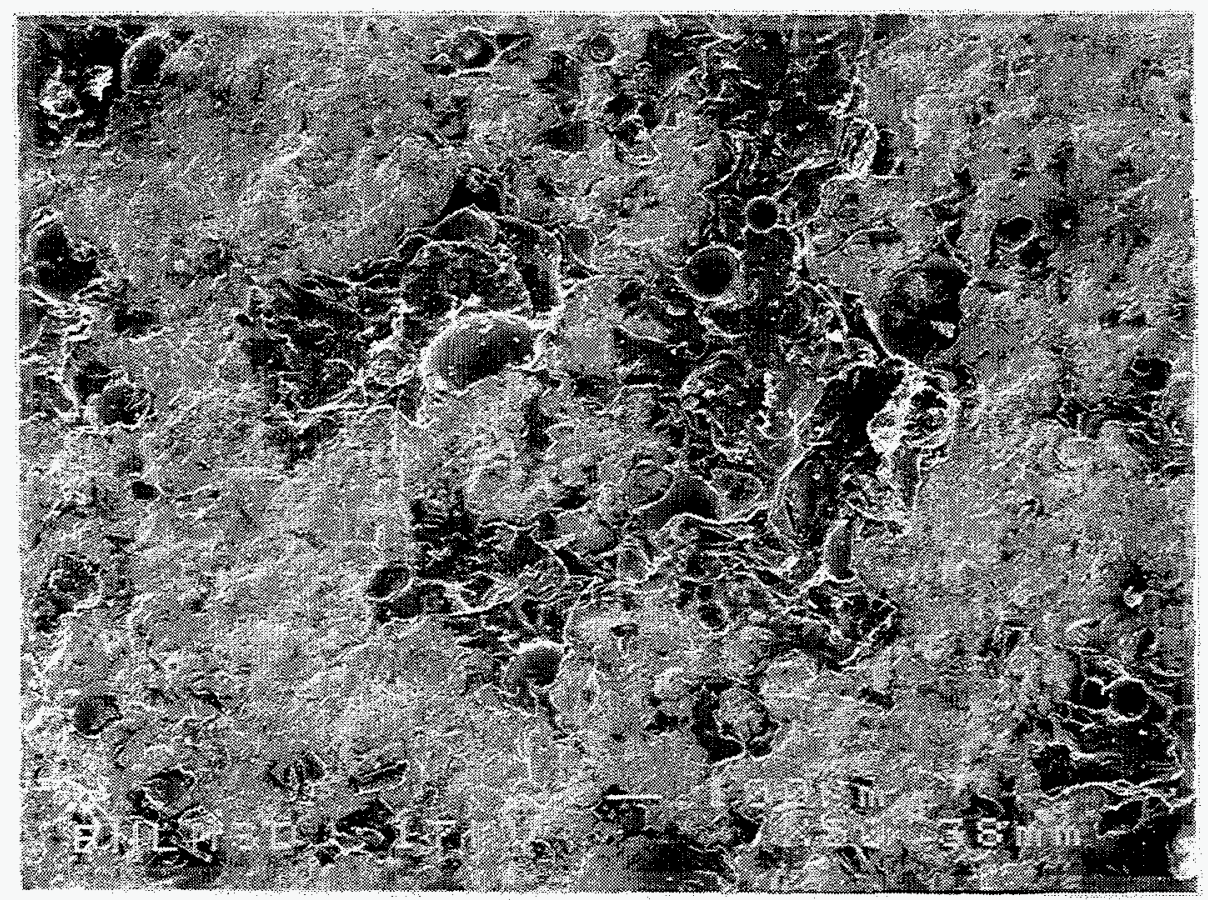

Figure 16. SEM micrograph of steel fracture surface showing mixed adhesive/cohesive fallure. Dark areas are polymer.

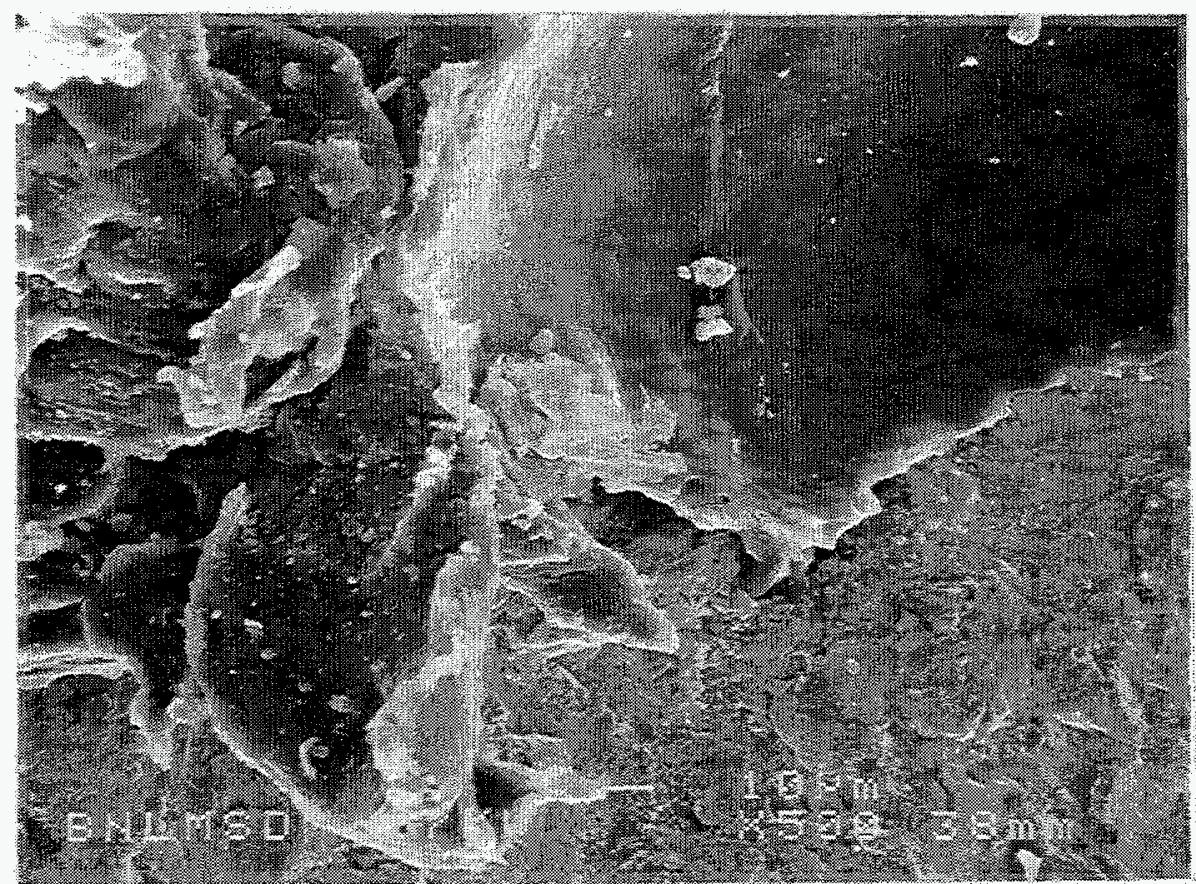

Figure 17. Higher magnification view on Fig. 16 showing falure through pore in polymer. 


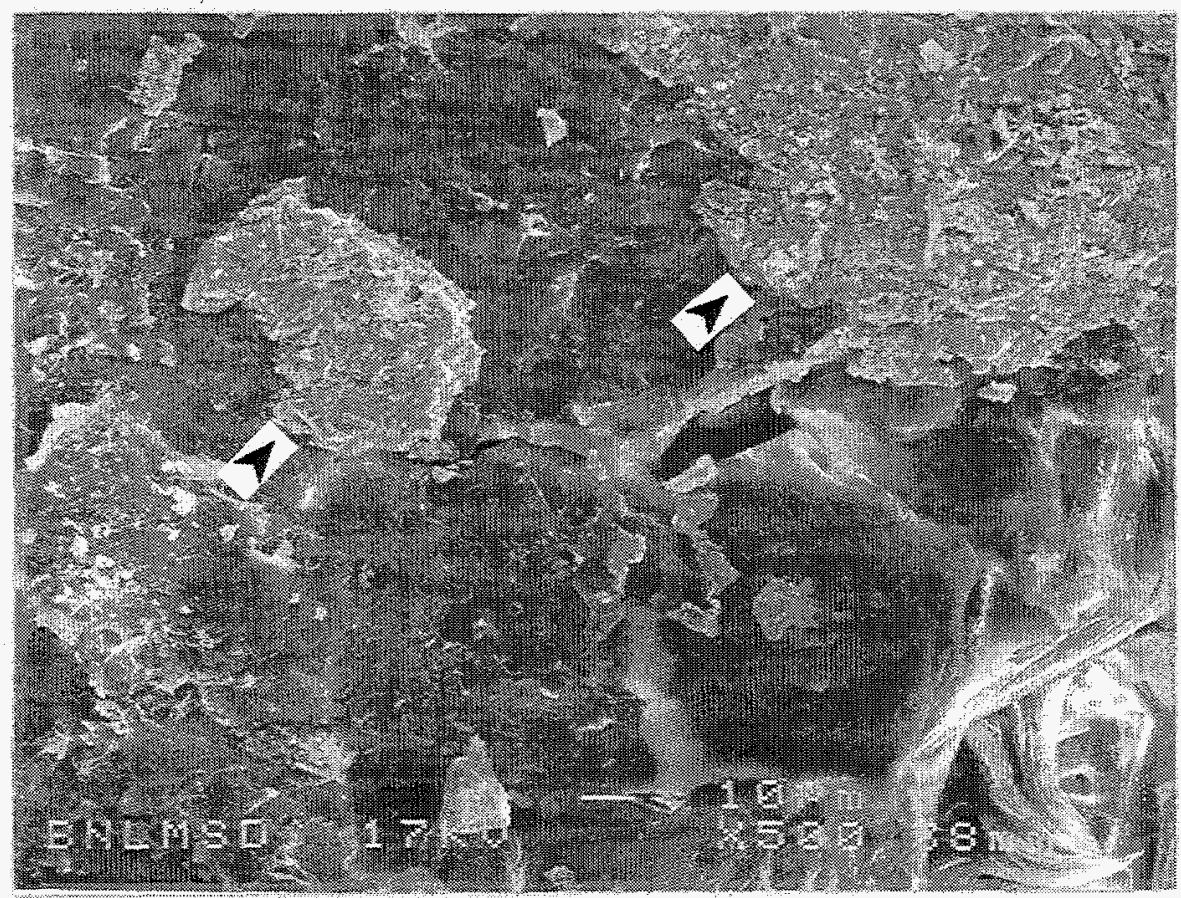

Figure 18. SEM micrograph of steel fracture surface. Dark areas are polymer, light areas are iron oxides (arrowed).

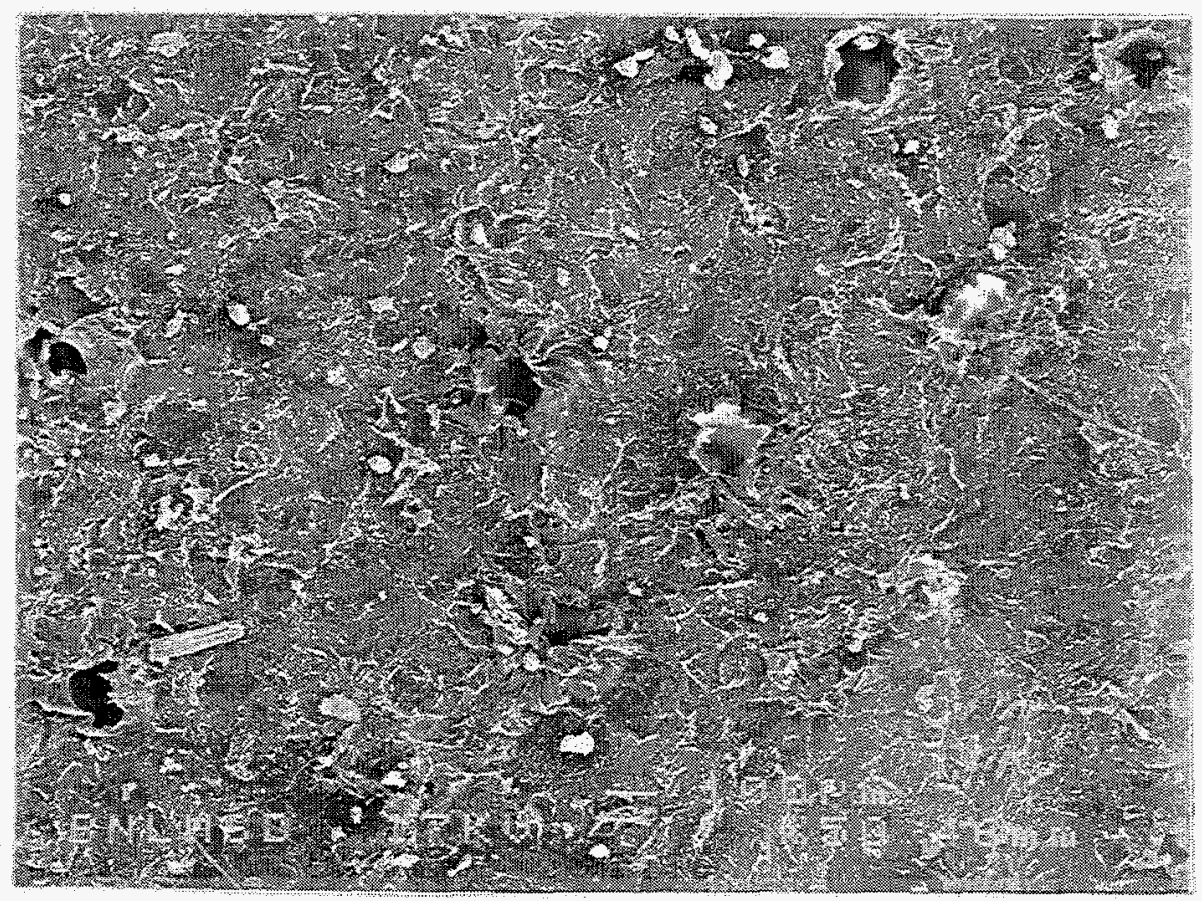

Figure 19. SEM micrograph of polymer fracture surface showing pores. 


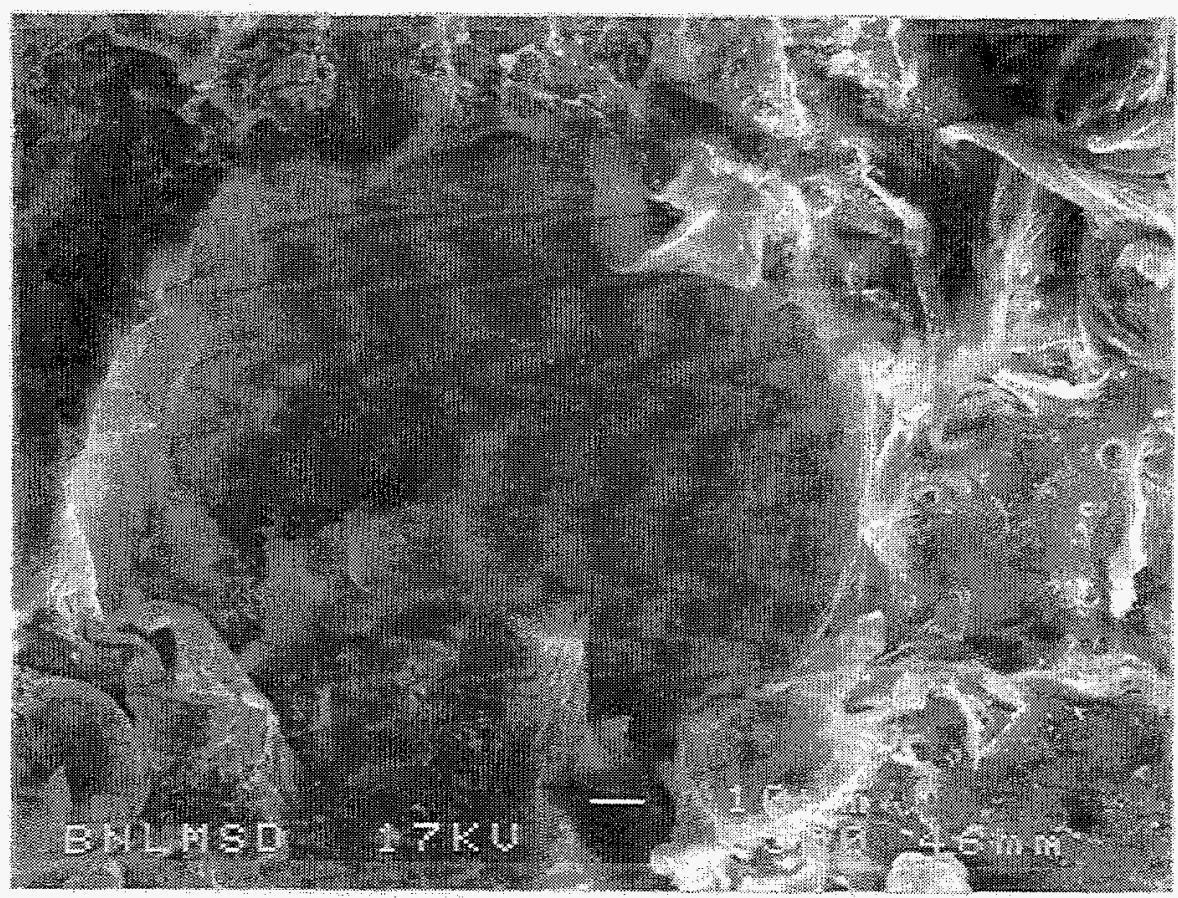

Figure 20. Polymer fracture surface at higher magnification showing ductile tearing around edge of pore.

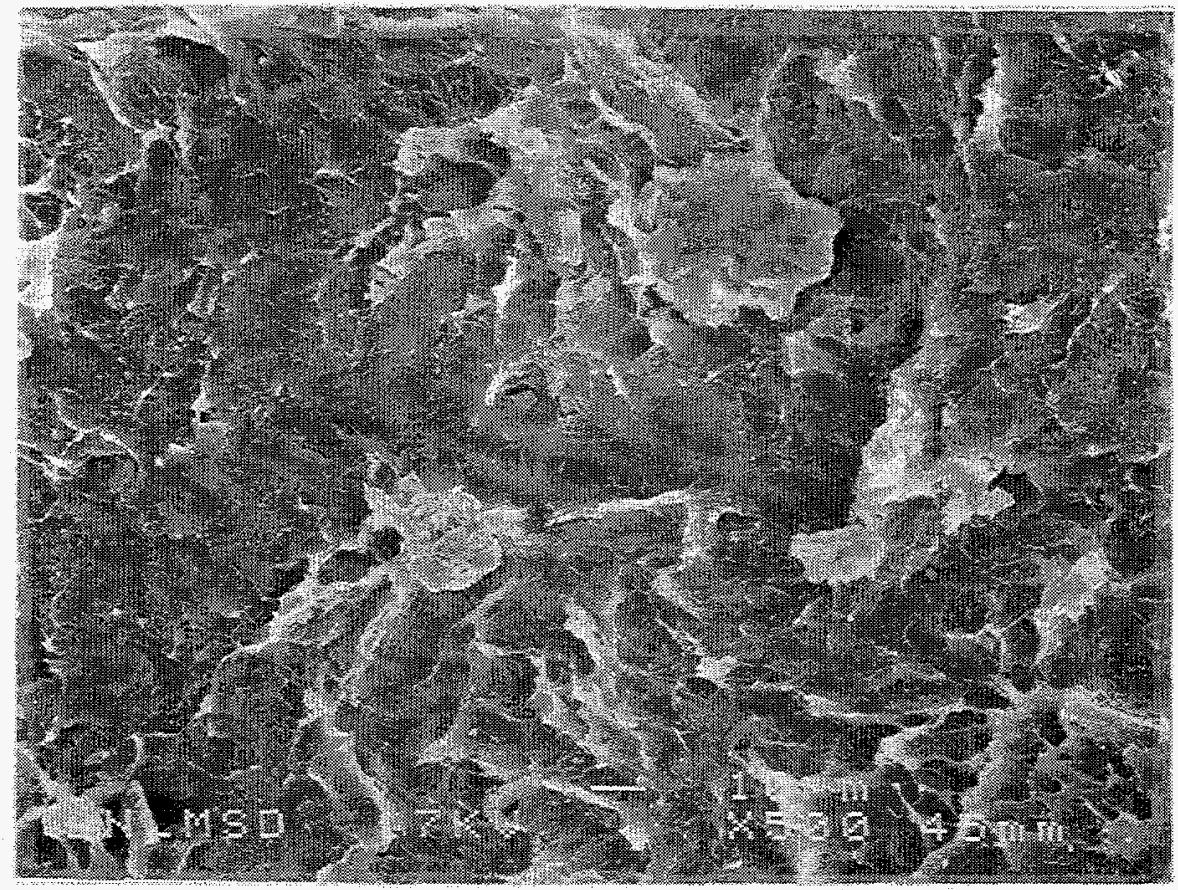

Figure 21. Polymer fracture surface showing tearing and coalescence of voids. 
products themselves. Figures 19-21 depict the fracture surface of the polymer. Figure 19 shows pores in the polymer surface. Ductile tearing of the polymer around the edges of a pore is evident in Figure 20 (1-5B). Tearing is visible in Figure 21 (1-5A), as is coalescence of voids $<5 \mu \mathrm{m}$ in diameter.

The ETFE coatings exposed to $T$. ferrooxidans exhibited biofouling in the liquid zone and surface staining from iron salts for above the liquid level. The coating material itself was not degraded by the bacteria. One of the panels displayed a blister $10 \mathrm{~mm}$ in diameter in the liquid zone. The coatings were removed with a razor blade to examine the steel condition. This method resulted in adhesive failure. It was found that spots of black corrosion products had formed at the interface between the steel and coating in both the liquid and vapour zones. Corrosion was more extensive in the upper half of the liquid zone than the lower. The least amount of corrosion was observed in a $5 \mathrm{~mm}$ band above the liquid level. This may be due to surface sealing by precipitated salts that act as an additional protective barrier.

Biofouling and surface staining were also observed for the EMAA coatings exposed to $T$. ferrooxidans and the polymer was not visibly attacked. The surface films were more adherent than for the ETFE coatings and could only be removed from the upper half of the liquid zone by scrubbing. Peel tests were performed and it was found that extensive surface corrosion had occurred beneath the coating. As was the case for the panels tested in brine, corrosion was manifested as black spots. The extent of corrosion was greater than that for the brine tests and was evident in both the liquid and vapour zones. The coatings used in the $T$. ferrooxidans tests were thinner, hence the results are not directly comparable. The distribution of the corrosion products differed for the bacteria tests. The individual spots of oxides increased in size with height of the liquid. The smaller spots of oxides corresponded with the greater extent of biofilm formation on the exposed surface of the coating. It is hypothesized that the biofilm tended to act as a sealant, thereby reducing penetration of aggressive species through the coating.

Directly above the liquid level was a band approximately $10 \mathrm{~mm}$ high that was completely devoid of visible corrosion. This apparently was a cathodic area and corresponded to tightly adherent iron salts on the external coating surface. Again, it is proposed that this surface layer acted was a sealant and actually improved the coating performance. The extent of corrosion on the steel substrates was similar for the EMAA and ETFE coatings.

Failure in these panels was totally adhesive. The peel load versus displacement curves showed similar form to those obtained from the panels exposed to brine. The strips cut from outside the test cell had relatively a constant load required to peel the coating. The average peel strength was $6.64 \mathrm{~N} / \mathrm{mm}$. Load versus displacement curves obtained from area of exposed coating had a bathtub shape with higher loads being measured outside the test cell. Plastic deformation of the EMAA also occurred in the latter areas. The extent of plastic yielding was greater than for the thicker coatings used in the brine tests due to higher bending 
stresses. The peel strengths in the corroded areas were as low as $0.46 \mathrm{~N} / \mathrm{mm}$. Peel forces were less variable where corrosion occurred than for the specimens tested in brine and this is attributed to the absence of cohesive failure which is associated with higher loads and more extensive corrosion. Figure 22 is an example of peel test results in the exposed area. The spike in the flat section of the curve correlated with the uncorroded area directly above the liquid level.

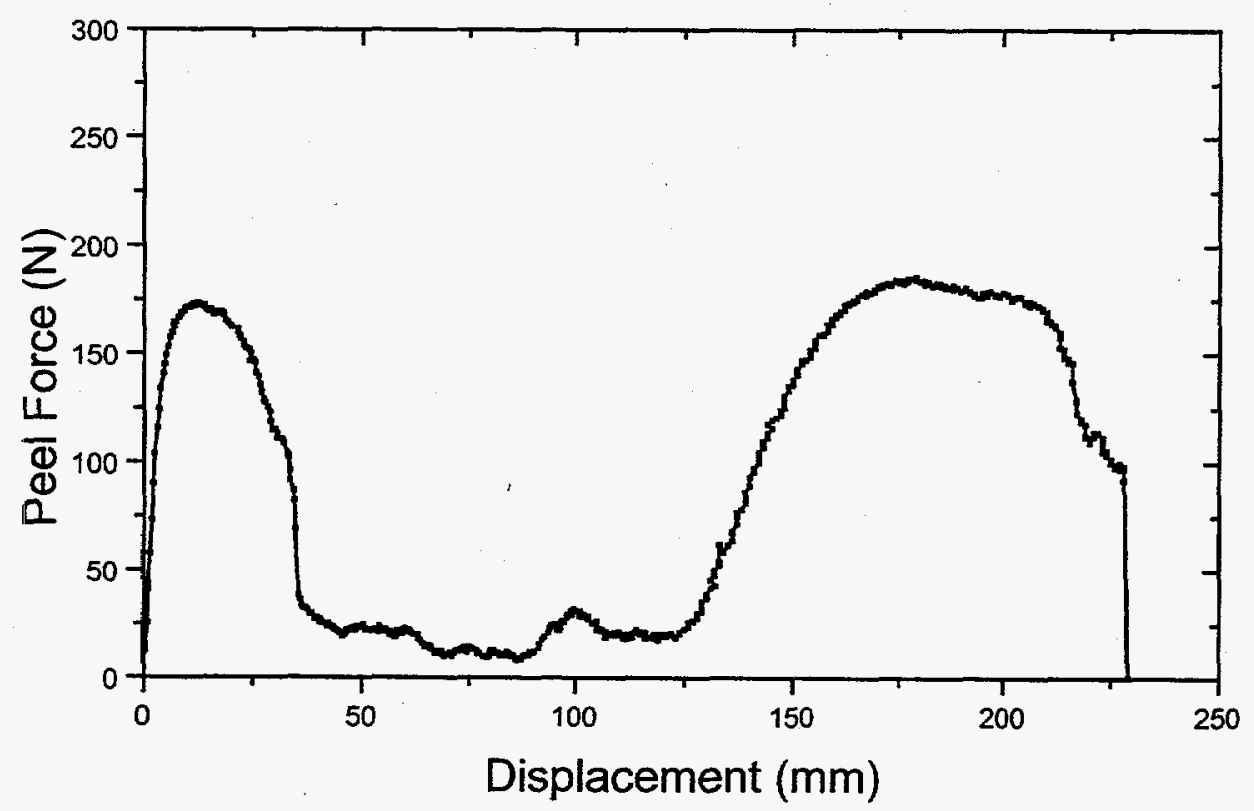

Figure 22. Peel force-displacement curve for EMAA exposed to $T$. ferrooxidans.

\subsection{Cathodic Disbondment Tests}

The rest potential of the unpolarized specimens after four weeks of exposure to brine ranged from -662 to $-695 \mathrm{mV}$ SCE. Pitting corrosion was evident at the coating holiday. Specimens polarized to potentials of -780 and $-900 \mathrm{mV} \mathrm{SCE}$ did not undergo any cathodic disbondment. Slight corrosion occurred at the holidays indicating that a more negative potential is required for adequate cathodic protection under the conditions studied. No apparent disbondment and slight corrosion occurred at a potential of $-1070 \mathrm{mV} \mathrm{SCE}$. When the potential was decreased to $-1500 \mathrm{mV}$ SCE one specimen exhibited disbondment. The diameter of the disbondment was $4.06 \mathrm{~mm}$, compared with the original holiday diameter of $3.2 \mathrm{~mm}$. 


\subsection{Abrasion Tests}

The thermal sprayed EMAA coating exhibited very slight wear at the conclusion of the stirred tank experiment. The percentage mass loss was $0.07 \%$. The abrasion resistance of this coating could be increased by adding a ceramic filler to form a polymer-ceramic composite. The Devcon coated tank showed negligible wear and the mass remained constant. Therefore, this coating has good abrasion resistance and is a suitable candidate for pilot-scale tests to protect the reactor vessels from the abrasive effects of sludge.

\subsection{DISCUSSION}

The coupon tests confirmed that corrosion of bare $316 \mathrm{~L}$ stainless steel could be expected in geothermal brine and sludges. This is in concurrence with many previous studies of corrosion in geothermal fluids at higher temperatures (e.g., 2-6). Higher corrosion rates would be predicted if the brine contains dissolved $\mathrm{H}_{2} \mathrm{~S}$ or $\mathrm{CO}_{2}$. Corrosion is also a potential problem for plant equipment exposed to the $T$. ferrooxidans biocatalyst and protective coatings are required. The EMAA coating was resistant to microbial degradation and protected the $316 \mathrm{~L}$ from corrosion in the coupon tests. The baked PVDF and ETFE coatings also afforded corrosion protection.

The ETFE coated panels were subject to disbondment and corrosion at the interface between mild steel substrate and polymer when tested in brine with the Atlas cell arrangement. The low residual adhesion in the exposed area suggests that this coating will have insufficient long-term durability for protection of mild steel from brine. Performance of the ETFE coatings was better in the T. ferrooxidans environment. However, substrate corrosion tends to preclude the mild steel-ETFE system from the application of interest.

The Atlas cell tests for the EMAA coatings exposed to brine showed that corrosion at the interface was also a problem and that adhesion decreased where corrosion occurred. It was not clear why one of the panels tended to undergo corrosion primarily in the vapour zone, while the nominally identical companion panel corroded in both the liquid and vapour zones. The EMAA coatings cannot be recommended for long-term protection of mild steel from brine under the planned operating conditions. Future work will repeat the same tests on $316 \mathrm{~L}$ substrates, since vessels of this material will be used in pilot scale biochemical processing of the geothermal residues. It is predicted that longevity of the $316 \mathrm{~L}$ will be extended by EMAA coatings, although further testing is required to confirm this. The EMAA coatings did not adequately protect mild steel from corrosive effects of the $T$. ferrooxidans medium under the test conditions. The tests did reveal that sealing of the surface by deposits from the medium improved the barrier effect of the coating. Therefore, superior performance could be achieved if porosity of the coating can be reduced. Although corrosion of mild steel occurred with both the ETFE and EMAA coatings, it should not be neglected that the test environments were severe and that corrosion would have been rapid in the absence of the coatings. 
The results from the initial cathodic disbondment tests in brine at room temperature indicate that the coating resists disbondment at potentials of -780 to $-1070 \mathrm{mV} \mathrm{SCE}$. However, corrosion of the mild steel substrate still occurred at these potentials. More negative potentials would increase the risk of disbondment. In addition, higher temperatures can be expected to increase the disbondment rate. These effects have been documented (7). Cathodic disbondment may also involve an initiation period (7). Hence, increased testing periods and elevated test temperatures are recommended before using the EMAA coatings in conjunction with cathodic protection at $55^{\circ} \mathrm{C}$.

\subsection{FUTURE WORK}

Assuming funding is available, the evaluation of Devcon ceramic-filled epoxy coatings will continue. It is also planned to test coatings under pilot-scale operating conditions so that realistic working conditions, including temperature cycling and abrasive wear, are incorporated. Other coatings such as glass flake vinyl and polyesters also have potential. The combined effects of sulphur-oxidizing bacteria and geothermal residue will be examined. A new variation of the biochemical treatment involves a chemical reagent step. Therefore, it is necessary to determine the corrosiveness of this reagent and suitable protective coatings. Thermal sprayed EMAA coatings will be tested further for protecting $316 \mathrm{~L}$ stainless steel. Also of interest is the use of thermal sprayed polymer-ceramic composites since these are expected to have improved abrasion resistance.

\subsection{CONCLUSIONS}

Thermal sprayed EMAA and ETFE polymers are resistant to attack by hypersaline brine, geothermal sludge and $T$. ferrooxidans. The coatings are not suitable for long-term protection of mild steel from these aggressive environments at $55^{\circ} \mathrm{C}$ due to corrosion and subsequent decrease in adhesion. EMAA has potential for protection $316 \mathrm{~L}$ stainless steel and for use in conjunction with cathodic protection. Devcon Brushable Ceramic has excellent abrasion resistance. Although the long-term durability tests on this latter coating are not complete, initial indications are that it appears suitable for the application of interest and will be used in the pilot-scale tests. Spray-and-bake ETFE and PVDF coatings displayed good performance in coupon tests.

\subsection{ACKNOWLEDGMENTS}

The author is grateful to Professor C.C. Berndt, Dr. J.A. Brogan and Mr. D. Otterson (SUNY at Stony Brook) for preparation of thermal sprayed specimens and conducting the peel tests. Thanks are also due to Mr. Ray Zatorski (Zatorski Coating Co.) for preparing some of the coated specimens and to Mr. Jeff Yablon (BNL) for supplying the T. ferrooxidans. 


\subsection{REFERENCES}

1. ASM Metals Handbook, Volume 13, Ninth Edition, Ohio, 1987.

2. W.R. Braithwaite, W.R. and K.A. Lichti, "Surface Corrosion of Metals in Geothermal Fluids at Broadlands, New Zealand," in ASTM STP 717, pp. 81-112, L.A. Casper and T.R. Pinchback, Eds., American Society for Testing and Materials, 1980

3. S.W. Borenstein, "Susceptibility of Stainless Steel Weldments to Microbiologically Influenced Corrosion," Materials Research Society Symposium Proceedings, Volume 294, pp. $353-360,1993$.

4. S.W. Borenstein, Microbiologically Influenced Corrosion Handbook, Industrial Press Inc., New York, 1994.

5. J.P. Carter and F.X. McCawley, "In Situ Corrosion Tests in Salton Sea Geothermal Brine Environments," Journal of Metals, 30, pp. 11-15, 1978.

6. S.D. Cramer and J.P. Carter, "Corrosion in Geothermal Brines of the Salton Sea Known Geothermal Resource Area," in ASTM STP 717, pp. 113-141, L.A. Casper and T.R. Pinchback, Eds., American Society for Testing and Materials, 1980.

7. D.K. Heffner, "Fluoropolymer Linings in the Transportation Industry," Materials Performance, 31, No. 7, pp. 33-36, 1992.

8. B. Little, P. Wagner and F. Mansfield, "An Overview of Microbiologically Influenced Corrosion," Electrochimica Acta, 37, No. 12, pp. 2185-2194, 1992.

9. P.J. Loustannau and D. Horton, "EMAA Thermoplastic Powder Coatings in Shop and Field Applications," Materials Performance, 33, No. 7, pp. 32-36, 1994.

10. D.D. Macdonald, B.C. Syrett and S.S. Wing, "The Use of Potential-pH Diagrams for the Interpretation of Corrosion Phenomena in High Salinity Geothermal Brines," Corrosion, 35, No. 1, pp. 1-11, 1979.

11. P.B. Needham, S.D. Cramer, J.P. Carter and F.X. McCawley, "Corrosion Studies in High-Temperature, Hypersaline Geothermal Brines," Corrosion '79, Paper 59, NACE, 1979.

12. E.T. Premuzic, M.S. Lin, J-Z. Hin and K. Hamilton, "Geothermal Waste Treatment Biotechnology," in Proceedings of World Geothermal Congress, pp. 2769-2772, Florence, 1995.

13. L.R. Scharfstein, "Effects of Composition, Structure, and Heat Treatment on the 
Corrosion Resistance of Stainless Steel," in Handbook of Stainless Steels, D. Peckner and I.M. Bernstein, McGraw-Hill, New York, 1977.

14. U. Steinsmo and J.I. Skar, "Factors Influencing the Rate of Cathodic Disbonding of Coatings," Corrosion, 50, No. 12, pp. 934-939, 1994.

15. B.C. Syrett, D.D. Macdonald and H. Shih, "Pitting Resistance of Engineering Materials in Geothermal Brines-I. Low Salinity Brine," Corrosion, 36, No. 3, pp. 130-139, 1980. 